\title{
The Expression of miRNAs in Human Ovaries, Oocytes, Extracellular Vesicles, and Early Embryos: A Systematic Review
}

\author{
Albert Salas-Huetos ${ }^{1, * \mathbb{D}}$, Emma R. James ${ }^{1,2}$, Kenneth I. Aston ${ }^{1}$, Timothy G. Jenkins ${ }^{1}$, \\ Douglas T. Carrell ${ }^{1,2,3}$ and Marc Yeste ${ }^{4, * \mathbb{D}}$ \\ 1 Andrology and IVF Laboratory, Division of Urology, Department of Surgery, University of Utah School of \\ Medicine, Salt Lake City, UT 84108, USA; Emma.James@utah.edu (E.R.J.); ki.aston@hsc.utah.edu (K.I.A.); \\ Tim.Jenkins@hsc.utah.edu (T.G.J.); douglas.carrell@hsc.utah.edu (D.T.C.) \\ 3 Department of Obstetrics and Gynecology, University of Utah School of Medicine, \\ Salt Lake City, UT 84108, USA \\ 4 Biotechnology of Animal and Human Reproduction (TechnoSperm), Unit of Cell Biology, Department of \\ Biology, Institute of Food and Agricultural Technology, Faculty of Sciences, University of Girona, \\ 17003 Girona, Spain \\ * $\quad$ Correspondence: albert.salas@utah.edu (A.S.-H.); marc.yeste@udg.edu (M.Y.); Tel.: +34-972419514 (M.Y.)
}

Received: 1 November 2019; Accepted: 3 December 2019; Published: 4 December 2019

\begin{abstract}
The recent discovery of microRNAs (miRNAs) in human reproductive tissues and cells indicates a possible functional role in reproductive function. However, the studies published to date in female reproductive tissues/cells and embryos are inconclusive and sometimes controversial. In order to update the knowledge of this field, the present study aimed to discuss, through a systematic review, the role of miRNAs in female human reproduction and early embryogenesis. We conducted a systematic review of the published literature in MEDLINE and EMBASE databases through June 2018 (plus a complementary search until July 2019), in accordance with the PRISMA guidelines. We have included descriptive and observational studies, in which fertile/infertile women were well-defined. The primary outcome was the miRNA expression in ovaries, oocytes, extracellular vesicles, and embryos. We identified 25,204 articles, of which 28 were selected for qualitative analysis: 18 in ovaries and extracellular vesicles, three in oocytes, and seven in embryos. The present systematic review of descriptive and observational studies demonstrates that aberrant miRNA expression in female reproductive tissues/cells and embryos is related with infertility and embryogenesis errors. The expression of specific miRNAs, particularly in extracellular vesicles, may be used in the future as biomarkers of infertility and prognostic tools of embryo development.
\end{abstract}

Keywords: miRNAs; extracellular vesicles; ovary; oocyte; embryo

\section{Introduction}

MicroRNAs (miRNAs) are single-stranded RNA molecules from 16-28 nucleotides in length (www.mirbase.org) that function to regulate gene expression by means of the formation of semi-complementary structures between mRNA and miRNAs in $3^{\prime}$ untranslated regions ( $3^{\prime}$ UTR) (in plants the mRNA-miRNA interaction is near perfect, whereas in animals, miRNAs bind in semi-complementarity with mRNA encoding regions) [1,2]. Each miRNA has hundreds of potential mRNA targets, due to the semi-complementary configuration [3]. Mediated by Argonaute (AGO) proteins and components of the RNA-induced silencing complex (RISC), miRNAs can act by the 
following mechanisms: (1) deadenylation of poly-A tails or, (2) interaction/inhibition with/of translation initiation factors $[4,5]$.

A very recent in silico high-throughput experimental strategy estimated that about 2,300 mature miRNAs exist in humans, 1,982 of which are currently annotated in miRBase v.22.1 (www.mirbase.org). The most recent version of miRBase (v22.1) contains 2,654 mature human miRNA sequences [6]. In 2002, a landmark article reported the presence of small RNAs in sperm cells [7]; later, the same authors described that they were probably miRNAs [8]. In parallel, other authors described the presence of miRNAs in all human reproductive tissues and cells [9,10], evidencing the role in male [11] and female [12] gametogenesis and embryo development $[13,14]$. The presence of miRNAs in these cells and tissues, as well as the known functions associated with these molecules, suggests that a deregulation of their expression may result in alterations in reproductive system and potentially in early embryogenesis.

Therefore, we conducted the first systematic review of high-quality studies published to date to clarify the existing association between miRNA expression in different female reproductive tissues and cells as well as the early embryo, and the potential associations with infertility and early embryogenesis. Although a meta-analytic analysis is not possible due to the heterogeneity of published articles, a well-designed systematic review is beneficial in consolidating the current body of evidence, which is sometimes inconclusive and controversial. This review is aimed at helping researchers to identify deficiencies and test new hypotheses on this field.

\section{Material and Methods}

\subsection{Search Strategy and Systematic Review Registration}

A systematic search was performed in the MEDLINE-Pubmed (http://www.ncbi.nlm.nih.gov/ pubmed) and the EMBASE (https://www.embase.com/\#search) databases. The search was performed on several occasions with the last screening search taking place on June 2018 (and a complimentary search until July 2019) without further restrictions on publication date in accordance with the guidelines and checklist of the Preferred Reporting Items for Systematic Reviews and Meta-Analyses (PRISMA) [15]. The protocol has been registered in the PROSPERO registry (PROSPERO 2018: CRD42018099793; http://www.crd.york.ac.uk/PROSPERO).

The search query and screening strategy aimed at collecting all records related to human infertility, and miRNAs using both Medical Subject Headings (MeSH) and keywords. The complete search strategy and filters included is available in Supplemental Appendix 1.

\subsection{Study Selection and Eligibility}

Titles and abstracts were screened in duplicate by two of the six authors (A.S-H. and M.Y.) for eligibility. A third author resolved disagreements (E.R.J.). A PICOS (Patient, Intervention, Comparator, Outcome, Study) design structure was used to develop the study questions and the inclusion/exclusion criteria (Supplemental Table S1). Studies were eligible for inclusion if they were human studies (descriptive, case-control, cross-sectional, observational prospective, and retrospective studies) in which fertile/infertile conditions were well-defined. The primary outcome was the miRNA expression level. Comparators were always a well-defined control/fertile group without interventions beyond the intrinsic IVF/ICSI procedures in some cases. After primary screening (evaluation of the scope of the study based on the title and abstract), the full texts of the selected articles were obtained. Regarding eligibility, randomized clinical trials (RCTs), animal studies, review articles, studies evaluating free circulating miRNAs, studies with gestational or specific female sexual tract tissues (e.g., fallopian tubes or endometrial tissue), studies in male reproductive cells/tissues, and studies with other types of small RNAs not included in the miRNA category were excluded. We conducted a complementary search of reference lists of articles and key journals for human studies after June 2018 until July 2019. 
After the secondary screening, and once compliance with all the inclusion/exclusion criteria was assessed, more full texts were obtained.

\subsection{Data Extraction and Quality Assessment}

We extracted the following information from each study: authors, year of publication, journal, title of the article, localization of the study, study participant age, infertility phenotype, number of participants (sample size), study design, primary outcome and aim of the study, and major findings. The NHLBI-NIH quality assessment tool was used to assess the quality of each study (https://www.nhlbi.nih.gov/health-topics/study-quality-assessment-tools). Similar to the publication selection process, disagreements were resolved by consensus between three authors (A.S-H., M.Y., and E.R.J.). The scale assesses different domains depending on study type. The complete quality assessment criteria are available in Supplemental Appendix 2. Studies with a score $\geq 3$ points for descriptive studies, $\geq 4$ points for case-control studies and $\geq 5$ points for retrospective/prospective and cross-sectional studies were considered of modest to good quality and were eligible for the present systematic review.

\section{Results}

\subsection{Identification and Selection of the Articles}

We identified 16,469 articles after a primary search by MEDLINE-Pubmed, and 8,735 articles after a primary search by EMBASE database (Figure 1). After analyzing the results $(n=25,204)$, we immediately excluded 2,569 records because they were duplicated $(n=819)$; they were conference papers $(n=1,559)$, comments, replies or letters to the Editor $(n=9)$; they were retracted papers $(n=2)$, or because they were not written in English $(n=180)$. The remaining 22,635 records were evaluated based on their title and abstract, and 22,343 were excluded. The remaining 292 articles were collected as full-texts, and 32 additional manuscripts were included after a complementary search. Therefore, the inclusion/exclusion criteria and quality scores were assessed in 324 full-text articles. One hundred and seventy-six of these 324 articles were excluded because they did not meet the inclusion/exclusion criteria, while 70 articles were excluded because they were review articles, two articles were excluded because their full-text was not available, 41 articles were excluded because they were studies in male reproductive tissues/cells, and seven articles were excluded because they did not reach the quality assessment threshold. Finally, after applying all of the eligibility parameters, 28 articles were used for qualitative analysis.

\subsection{Summary of Selected Studies}

Of the 28 articles included, 18 evaluated the miRNAs in ovaries and/or extracellular vesicles (i.e., exosomes and microvesicles) [9,16-32]; three in oocytes [33-35]; and seven in embryos [36-42].

\subsubsection{Ovaries and/or Extracellular Vesicles (Exosomes and Microvesicles)}

Eighteen studies investigating miRNAs found in ovaries and extracellular vesicles isolated from follicular fluid are included in this systematic review and are summarized in Table $1 \mathrm{~A}$. The quality scores of these articles are the following: descriptive studies mean $=5 / 9$, case-control studies mean $=5.9 / 12$, prospective studies mean $=7.5 / 14$, and cross-sectional studies mean $=8 / 14$. 


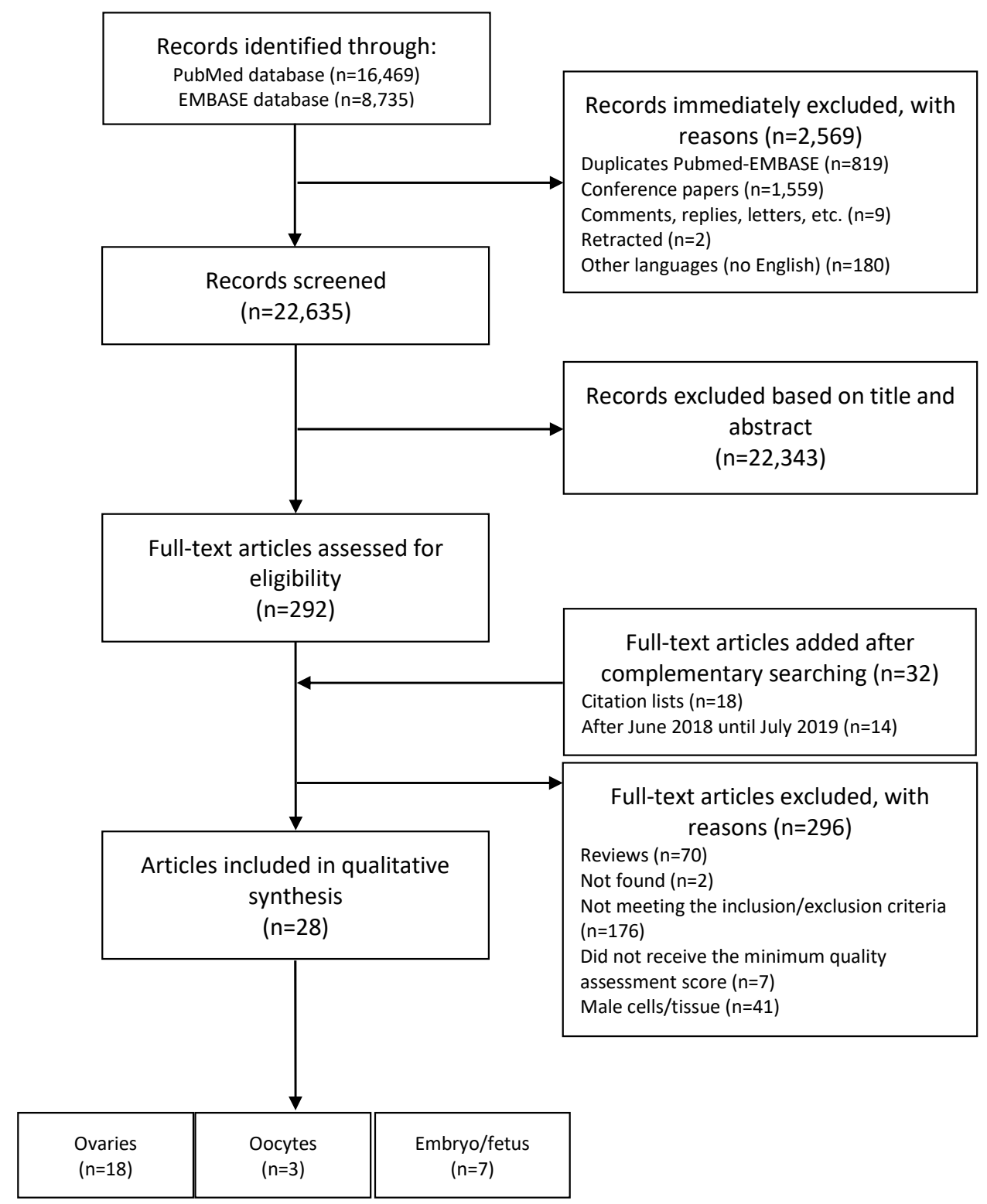

Figure 1. Flow chart of the literature search and selection process. 
Table 1. Summary of the studies in female reproductive cells and tissues: (A) ovary and extracellular vesicles (exosomes and microvesicles), and (B) oocytes.

\begin{tabular}{|c|c|c|c|c|c|c|c|c|}
\hline Reference & Location & Age (years) & Population Studied & Study Design & Outcome and Aim & $\begin{array}{c}\text { Analysis and } \\
\text { Normalization Methods }\end{array}$ & Principal Conclusion & Quality Scor \\
\hline \multicolumn{9}{|c|}{ (A) Ovary and extracellular vesicles (exosomes and microvesicles) } \\
\hline $\begin{array}{l}\text { [9] (Liang et al., } \\
\text { 2007) }\end{array}$ & USA & ND & 1 ovary & Descriptive & $\begin{array}{c}\text { To identify miRNA } \\
\text { expression patterns in } \\
\text { human tissues (including } \\
\text { ovary). }\end{array}$ & $\begin{array}{l}\text { Analysis: qRT-PCR. } \\
\text { Normalization: Average } \\
\text { of miR-30e, miR-92, } \\
\text { miR-92N, and miR-423. }\end{array}$ & $\begin{array}{l}\text { A total of } 216 \text { miRNAs are } \\
\text { expressed in human ovaries. }\end{array}$ & $4 / 9$ \\
\hline $\begin{array}{l}\text { [22] (Sang et al., } \\
\text { 2013) }\end{array}$ & China & $\begin{array}{l}\text { Desciptive: ND. } \\
\text { Cases: } 29.09 \pm \\
0.70 \text { Control: } \\
30.83 \pm 0.90\end{array}$ & $\begin{array}{c}\text { Follicular fluid and } \\
\text { microvesicles. } \\
\text { Descriptive: } 20 \text { women } \\
\text { undergoing ICSI. Cases: } \\
22 \text { PCOS patients Control: } \\
22 .\end{array}$ & Descriptive & $\begin{array}{l}\text { To identify cell-free } \\
\text { miRNAs in human } \\
\text { follicular fluid and to } \\
\text { investigate the function } \\
\text { of these miRNAs in vitro } \\
\text { and any roles they play in } \\
\text { PCOS. }\end{array}$ & $\begin{array}{l}\text { Analysis: qRT-PCR. } \\
\text { Normalization: U6 RNA. }\end{array}$ & $\begin{array}{l}\text { Identification of hsa-miRNA-19b, } \\
24 \text {, and } 222 \text { in human follicular } \\
\text { fluid and another } 538 \text { known } \\
\text { miRNAs. The expression levels of } \\
\text { hsa-miRNA- } 132 \text { and } 320 \text { were } \\
\text { significantly lower in controls than } \\
\text { in PCOS patients. }\end{array}$ & $4 / 9$ \\
\hline $\begin{array}{c}\text { [23] } \\
\text { (Santonocito et } \\
\text { al., 2014) }\end{array}$ & Italy & $<35$ & $\begin{array}{l}\text { FF exosomes from } 15 \\
\text { women undergoing ICSI }\end{array}$ & Descriptive & $\begin{array}{l}\text { To characterize } \\
\text { well-represented } \\
\text { miRNAs in human FF } \\
\text { and exosomes. }\end{array}$ & $\begin{array}{l}\text { Analysis: qRT-PCR. } \\
\text { Normalization: Average } \\
\text { of miR-25, miR-28-3p, } \\
\text { and miR-145. }\end{array}$ & $\begin{array}{l}37 \text { miRNAs upregulated in human } \\
\text { FF compared with in plasma ( } 15 \\
\text { miRNAs were found to be } \\
\text { upregulated in total FF compared } \\
\text { with in plasma; } 10 \text { miRNAs were } \\
\text { carried by exosomes, while five } \\
\text { were not). } 22 \text { miRNAs were } \\
\text { present exclusively in exosomes. }\end{array}$ & $6 / 9$ \\
\hline $\begin{array}{l}\text { [24] (Tong et al., } \\
\text { 2014) }\end{array}$ & China & $29.16 \pm 2.7$ & 5 women (CRC and COC) & Descriptive & $\begin{array}{l}\text { To determine the miRNA } \\
\text { expression profiles, via } \\
\text { NGS technology, of CRCs } \\
\text { and COCs. }\end{array}$ & $\begin{array}{l}\text { Analysis: RNA seq and } \\
\text { qRT-PCR validation. } \\
\text { Normalization: U6. }\end{array}$ & $\begin{array}{l}\text { A total of } 785 \text { and } 799 \text { annotated } \\
\text { miRNAs were identified in CRCs } \\
\text { and COCs respectively. Different } \\
\text { expression patterns in CRCs and } \\
\text { COCs were detected in } 72 \\
\text { annotated miRNAs. }\end{array}$ & $6 / 9$ \\
\hline $\begin{array}{l}\text { [16] (Cai et al., } \\
\text { 2017) }\end{array}$ & China & $29 \pm 3.5$ & $\begin{array}{l}\text { GC. Cases: } 25 \text { women } \\
\text { with PCOS. Controls } 20 \\
\text { women wihtout PCOS. }\end{array}$ & Case-control & $\begin{array}{l}\text { To investigate the effect of } \\
\text { miR-145 on cell } \\
\text { proliferation and the } \\
\text { underlying mechanism of } \\
\text { miR-145 in isolated } \\
\text { human GCs from the } \\
\text { aspirated follicular fluid } \\
\text { in women with PCOS. }\end{array}$ & $\begin{array}{c}\text { Analysis: qRT-PCR. } \\
\text { Normalization: GAPDH } \\
\text { or U6. }\end{array}$ & $\begin{array}{l}\text { miR-145 is downregulated in } \\
\text { human GCs from PCOS when } \\
\text { compared with control subjects. } \\
\text { Insulin receptor substrate } 1 \text { (IRS1) } \\
\text { gene is a direct target of miR-145. }\end{array}$ & $6 / 12$ \\
\hline $\begin{array}{l}\text { [25] (Chen et al., } \\
\text { 2017) }\end{array}$ & China & $\begin{array}{c}\text { NOR: } 30.57 \pm \\
\text { 2.69. DOR: } 33.74 \\
\quad \pm 3.25\end{array}$ & $\begin{array}{l}\text { COC. Cases: } 10 \text { women } \\
\text { with DOR. Controls: } 10 \\
\text { women with NOR }\end{array}$ & Case-control & $\begin{array}{c}\text { To comprehensively } \\
\text { characterize miRNA } \\
\text { expression profiles in } \\
\text { cumulus cells of DOR } \\
\text { patients. }\end{array}$ & $\begin{array}{l}\text { Analysis: RNA seq and } \\
\text { qRT-PCR validation. } \\
\text { Normalization: U6. }\end{array}$ & $\begin{array}{c}79 \text { annotated miRNAs, and } 5 \text { novel } \\
\text { miRNAs were identified } \\
\text { differentially expressed between } \\
\text { DOR and NOR. mTOR pathway } \\
\text { and meiosis-associated biological } \\
\text { processes were enriched in the } \\
\text { DE-miRNAs }\end{array}$ & $5 / 12$ \\
\hline
\end{tabular}


Table 1. Cont

\begin{tabular}{|c|c|c|c|c|c|c|c|c|}
\hline Reference & Location & Age (years) & Population Studied & Study Design & Outcome and Aim & $\begin{array}{c}\text { Analysis and } \\
\text { Normalization Methods }\end{array}$ & Principal Conclusion & Quality Score \\
\hline $\begin{array}{l}\text { [27] (Eisenberg } \\
\text { et al., 2017) }\end{array}$ & Israel & $\begin{array}{c}<35 \text {. PCOS: } 26.9 \\
\pm 4.3 \text { MIF: } 26.8 \\
\pm 4.7\end{array}$ & $\begin{array}{l}\text { GC. Cases: } 15 \text { normally } \\
\text { ovulating with pure male } \\
\text { infertility factor, and } 18 \\
\text { with PCOS. Controls: } 7 \\
\text { normally ovulating. }\end{array}$ & Case-control & $\begin{array}{l}\text { To study the role of } \\
\text { micro-RNA } \\
\text { (miRNA)-200b and } \\
\text { miRNA-429 in human } \\
\text { ovulation and to measure } \\
\text { their expression levels in } \\
\text { ovulatory and } \\
\text { anovulatory patients. }\end{array}$ & $\begin{array}{l}\text { Analysis: qRT-PCR. } \\
\text { Normalization: U6. }\end{array}$ & $\begin{array}{l}\text { Very low expression levels were } \\
\text { detected for the two miRNAs in } \\
\text { granulosa cells, with } \\
\text { hsa-miRNA-200b expression } \\
\text { relatively higher than miRNA- } 429 \text {. } \\
\text { No significant expression } \\
\text { difference of any of these miRNAs } \\
\text { was identified in the GLCs of the } \\
\text { two groups analyzed. }\end{array}$ & $5 / 12$ \\
\hline $\begin{array}{l}\text { [28] (Fu et al., } \\
\text { 2018) }\end{array}$ & China & $\begin{array}{c}<40 . \text { Control: } \\
\text { 29.89 } \pm 3.16 \text {. } \\
\text { Cases: } 30.94 \pm \\
3.82\end{array}$ & $\begin{array}{c}91 \text { individual FF. Cases: } \\
53 \text { no blastocysts. } \\
\text { Controls: } 38 \text { viable } \\
\text { blastocysts }\end{array}$ & Case-control & $\begin{array}{l}\text { To screen miRNAs in } \\
\text { human follicular fluid } \\
\text { and to explore the } \\
\text { relationship between } \\
\text { miRNA expression and } \\
\text { blastocyst formation }\end{array}$ & $\begin{array}{c}\text { Analysis: qRT-PCR } \\
\text { screening and qRT-PCR } \\
\text { validation. } \\
\text { Normalization: U6. }\end{array}$ & $\begin{array}{c}13 \text { miRNAs (hsa-miR-185, 202, 22, } \\
224,29 \mathrm{c}, 30 \mathrm{a}-3 \mathrm{p}, 378,382,424,432, \\
497,520 \mathrm{c}-3 \mathrm{p} \text { and } 663 \mathrm{~B} \text { ) were } \\
\text { up-regulated, and three miRNAs } \\
\text { (hsa-miR-1274a, 139-5p and 150) } \\
\text { were down-regulated in cases } \\
\text { compared with controls. In the } \\
\text { validation, the expression level of } \\
\text { miR-663B was found to be } \\
\text { significantly higher in cases than in } \\
\text { controls. }\end{array}$ & $5 / 12$ \\
\hline $\begin{array}{l}\text { [29] (Karakaya } \\
\text { et al., 2015) }\end{array}$ & Turkey & $\begin{array}{c}4 \text { groups: }<35 \\
35-37,38-40 \\
\quad>40 .\end{array}$ & $\begin{array}{l}\text { COC in } 189 \text { women } \\
\text { undergoing IVF-ICSI. } \\
\text { Cases: } 24 \\
\text { poor-responders. } \\
\text { Controls: } 32 \text { non-poor } \\
\text { responders. }\end{array}$ & Case-control & $\begin{array}{l}\text { To analyze the association } \\
\text { of miRNA expression } \\
\text { with the number of } \\
\text { oocytes retrieved, } \\
\text { in women undergoing } \\
\text { in vitro fertilization (IVF). }\end{array}$ & $\begin{array}{c}\text { Analysis: Microarray } \\
\text { screening and qRT-PCR } \\
\text { validation. } \\
\text { Normalization: RNU43. }\end{array}$ & $\begin{array}{l}\text { MicroRNA microarray analysis } \\
\text { showed up-regulation of } 16 \\
\text { miRNAs and down-regulation of } \\
88 \text { miRNAs in poor responders. } \\
\text { qRT-PCR confirmed that } \\
\text { miR-21-5p expression was } \\
\text { significantly up-regulated in poor } \\
\text { responders, whereas miR-21-3p } \\
\text { expression was significantly lower. }\end{array}$ & $5 / 12$ \\
\hline $\begin{array}{l}\text { [30] (Luo et al., } \\
\text { 2019) }\end{array}$ & China & $\begin{array}{c}\text { Poor ovarian } \\
\text { response }(37 \pm \\
3.16), \text { PCOS }(27 \\
\pm 3.26), \text { normal } \\
\text { patients }(29 \pm \\
3.22) .\end{array}$ & $\begin{array}{c}\text { GC. Cases: poor ovarian } \\
\text { response }(n=7), \text { PCOS } \\
(n=20) \text {. Controls: } \\
\text { normal patients }(n=18) .\end{array}$ & Case-control & $\begin{array}{l}\text { To determine the } \\
\text { microRNA (miRNA) } \\
\text { profiles in GCs from the } \\
\text { FF of patients with } \\
\text { varying levels of ovarian } \\
\text { reserve function. }\end{array}$ & Analysis: RNA seq. & $\begin{array}{l}\text { Identified } 20 \text { conserved and } 3 \\
\text { novel miRNAs that were } \\
\text { upregulated in the poor ovarian } \\
\text { response group and } 30 \text { conserved } \\
\text { miRNAs and } 1 \text { novel miRNA that } \\
\text { were upregulated in the PCOS } \\
\text { group. }\end{array}$ & $7 / 12$ \\
\hline
\end{tabular}


Table 1. Cont

\begin{tabular}{|c|c|c|c|c|c|c|c|c|}
\hline Reference & Location & Age (years) & Population Studied & Study Design & Outcome and Aim & $\begin{array}{c}\text { Analysis and } \\
\text { Normalization Methods } \\
\end{array}$ & Principal Conclusion & Quality Score \\
\hline $\begin{array}{l}\text { [17] (Roth et al., } \\
\text { 2014) }\end{array}$ & USA & $\begin{array}{l}\text { PCOS: } 33.1 \pm 4.4 \text {. } \\
\text { Oocyte donors: } \\
27.1 \pm 3.6\end{array}$ & $\begin{array}{l}\text { FF. Cases: PCOS }(n=10) \text {. } \\
\text { Controls: Oocyte donors } \\
\qquad(n=10) .\end{array}$ & Case-control & $\begin{array}{l}\text { To determine if miRNAs } \\
\text { are differentially } \\
\text { expressed in the FF of } \\
\text { women with PCOS } \\
\text { compared to fertile } \\
\text { oocyte donors }\end{array}$ & $\begin{array}{c}\text { Analysis: qRT-PCR } \\
\text { screening and qRT-PCR } \\
\text { validation. } \\
\text { Normalization: } \\
\text { U6snRNA. }\end{array}$ & $\begin{array}{l}29 \text { miRNAs are differentially } \\
\text { expressed between PCOS and OD } \\
\text { samples. In the validation step } \\
\text { only five of these upregulated } \\
\text { miRNAs (hsa-miR-9, 18b, 32, 34c, } \\
\text { and 135a) displayed a significant } \\
\text { increase in expression in the PCOS } \\
\text { group compared to OD controls. }\end{array}$ & $7 / 12$ \\
\hline $\begin{array}{l}\text { [18] (Scalici et } \\
\text { al., 2016) }\end{array}$ & France & $19-43$ & $\begin{array}{l}\text { FF. Cases: } 30 \text { women } \\
\text { with PCOS. Controls: } 91 \\
\text { women with normal } \\
\text { ovarian reserve. }\end{array}$ & Case-control & $\begin{array}{l}\text { To investigate the } \\
\text { expression profiles of five } \\
\text { circulating miRNAs } \\
\text { (let-7b, miR-29a, miR-30a, } \\
\text { miR-140 and miR-320a) } \\
\text { in human FF }\end{array}$ & $\begin{array}{l}\text { Analysis: qRT-PCR. } \\
\text { Normalization: miR-16. }\end{array}$ & $\begin{array}{l}\text { Hsa-miR-30a was significantly } \\
\text { up-regulated, while miR-140 and } \\
\text { let-7b were significantly } \\
\text { down-regulated in FF pools from } \\
\text { patients with PCOS ( } n=30) \\
\text { compared to women with normal } \\
\text { ovarian reserve. }\end{array}$ & $6 / 12$ \\
\hline $\begin{array}{l}\text { [19] (Shi et al., } \\
\text { 2015) }\end{array}$ & China & $\begin{array}{l}\text { Non-PCOS }(28.5 \\
\pm 3.6) . \text { PCOS } \\
(28.3 \pm 3.3) .\end{array}$ & $\begin{array}{l}\text { COC. Cases: PCOS } \\
(n=24) \text {. Controls: } \\
\text { Non-PCOS }(n=24) .\end{array}$ & Case-control & $\begin{array}{l}\text { To compare the } \\
\text { expression of miRNAs in } \\
\text { COC from PCOS and } \\
\text { non-PCOS women. }\end{array}$ & $\begin{array}{c}\text { Analysis: qRT-PCR } \\
\text { screening and qRT-PCR } \\
\text { validation. } \\
\text { Normalization: ND. }\end{array}$ & $\begin{array}{l}\text { Hsa-miR-483-5p and 486-5p are } \\
\text { significantly decreased in COC of } \\
\text { PCOS patients compared with } \\
\text { non-PCOS. Four predicted genes, } \\
\text { SOCS3, SRF, PTEN and FOXO1, } \\
\text { were significantly increased in } \\
\text { PCOS COC, and IGF2 was } \\
\text { significantly decreased in PCOS } \\
\text { COC. }\end{array}$ & $7 / 12$ \\
\hline $\begin{array}{l}\text { [20] (Wang et al., } \\
\text { 2018) }\end{array}$ & China & $\begin{array}{c}\text { Non-PCOS } \\
(30.00 \pm 0.74) \\
\text { PCOS }(28.67 \pm \\
0.675)\end{array}$ & $\begin{array}{l}\text { GC. Cases: } 25 \text { PCOS. } \\
\text { Controls: } 17 \text { non-PCOS } \\
\text { healthy women. }\end{array}$ & Case-control & $\begin{array}{l}\text { To characterize the } \\
\text { function of } \\
\text { microRNA-27a-3p } \\
\text { (miR-27a-3p) in PCOS }\end{array}$ & $\begin{array}{l}\text { Analysis: qRT-PCR. } \\
\text { Normalization: U6 RNA. }\end{array}$ & $\begin{array}{l}21 \text { miRNAs were upregulated and } \\
38 \text { were downregulated in PCOS } \\
\text { GCs. Hsa-miR-27a-3p was } \\
\text { significantly increased in both } \\
\text { excised GCs and the ovaries of } \\
\text { patients with PCOS compared } \\
\text { with the controls. }\end{array}$ & $6 / 12$ \\
\hline $\begin{array}{l}\text { [21] (Xu et al., } \\
\text { 2015) }\end{array}$ & China & $\begin{array}{c}\text { Non-PCOS } \\
(29.43 \pm 3.92) \\
\text { PCOS }(28.76 \pm \\
3.51)\end{array}$ & $\begin{array}{l}\text { GC. Cases: } 21 \text { women } \\
\text { with PCOS. Controls: } 20 \\
\text { women without PCOS. }\end{array}$ & Case-control & $\begin{array}{l}\text { To describe the altered } \\
\text { miRNA expression } \\
\text { profiles and miRNA } \\
\text { targeted signaling } \\
\text { pathways in PCOS. }\end{array}$ & $\begin{array}{l}\text { Analysis: RNAseq } \\
\text { screening and qRT-PCR } \\
\text { validation. } \\
\text { Normalization: U6. }\end{array}$ & $\begin{array}{l}\text { A total of } 59 \text { known miRNA were } \\
\text { identified that are differentially } \\
\text { expressed in PCOS cumulus } \\
\text { granulosa cells, including } 21 \\
\text { miRNAs increased and } 38 \\
\text { miRNAs decreased. Notch } \\
\text { signaling, regulation of hormone, } \\
\text { and energy metabolism of the } \\
\text { DE-miRNA target genes. }\end{array}$ & $6 / 12$ \\
\hline
\end{tabular}


Table 1. Cont

\begin{tabular}{|c|c|c|c|c|c|c|c|c|}
\hline Reference & Location & Age (years) & Population Studied & Study Design & Outcome and Aim & $\begin{array}{c}\text { Analysis and } \\
\text { Normalization Methods }\end{array}$ & Principal Conclusion & Quality Score \\
\hline $\begin{array}{l}\text { [26] (Diez-Fraile } \\
\text { et al., 2014) }\end{array}$ & Belgium & $\begin{array}{l}\text { Younger group } \\
\text { (29.3-30.3), } \\
\text { older group } \\
(38.7-42.4)\end{array}$ & $\begin{array}{c}16 \text { women. Young age: }< \\
31 \text { years }(n=8) ; \text { advanced } \\
\text { age: }>38 \text { years }(n=8)\end{array}$ & Prospective & $\begin{array}{l}\text { To report the presence of } \\
\text { miRNAs in human FF } \\
\text { and identify a set of } \\
\text { miRNAs that are } \\
\text { differentially expressed in } \\
\text { older women compared } \\
\text { to younger women. }\end{array}$ & $\begin{array}{c}\text { Analysis: qRT-PCR } \\
\text { screening and qRT-PCR } \\
\text { validation. } \\
\text { Normalization: } \\
\text { hsa-miR-483-5p. }\end{array}$ & $\begin{array}{l}\text { Hsa-miR-21-5p was present at } \\
\text { significantly higher levels in FF } \\
\text { from young women, whereas } \\
\text { hsa-miR-99b-3p, } 134 \text { and } 190 \mathrm{~b} \\
\text { were present at significantly higher } \\
\text { levels in the FF from older women. }\end{array}$ & $8 / 14$ \\
\hline $\begin{array}{l}\text { [32] (Moreno et } \\
\text { al., 2015) }\end{array}$ & Spain & $\begin{array}{c}\text { Younger group } \\
(32.93 \pm 2.19), \\
\text { older group } \\
(38.20 \pm 0.86)\end{array}$ & $\begin{array}{l}\text { Stage 1: Younger group: } \\
<35(n=15) \text {, older group: } \\
>37(n=15) \text {. Stage 2: MII } \\
\text { vs. GV }(n=12) \text { and MI vs. } \\
\text { MII }(n=9) \text {, each patient } \\
\text { acted as her own control. }\end{array}$ & Prospective & $\begin{array}{l}\text { To determine whether } \\
\text { there is any difference in } \\
\text { the FF miRNA profiles } \\
\text { from IVF patients } \\
\text { according to their age and } \\
\text { oocyte maturation stage. }\end{array}$ & $\begin{array}{c}\text { Analysis: qRT-PCR } \\
\text { screening and qRT-PCR } \\
\text { validation. } \\
\text { Normalization: RNU6B. }\end{array}$ & $\begin{array}{l}\text { hsa-miR-424, which is present in } \\
\text { higher proportions in FF from } \\
\text { patients with advanced age. When } \\
\text { we compared the FF from MII } \\
\text { versus GV oocytes, they found } 13 \\
\text { differentially expressed miRNAs. } \\
\text { When we compared FF from MII } \\
\text { versus MI, they found seven } \\
\text { differentially expressed miRNAs in } \\
\text { MII. }\end{array}$ & $7 / 14$ \\
\hline $\begin{array}{l}\text { [31] (Martinez et } \\
\text { al., 2018) }\end{array}$ & USA & $28.9-33.7$ & $\begin{array}{l}126 \text { women. EV-miRNAs } \\
\text { in FF from oocytes with } \\
\text { normal fertilization } \\
(n=93) \text { and from oocytes } \\
\text { that failed to fertilize } \\
(n=33) .\end{array}$ & Cross-sectional & $\begin{array}{l}\text { To assess whether EV } \\
\text { miRNAs from FF can } \\
\text { serve as biomarkers for } \\
\text { fertilization status and } \\
\text { day } 3 \text { embryo quality. }\end{array}$ & $\begin{array}{l}\text { Analysis: qRT-PCR. } \\
\text { Normalization: global } \\
\text { mean. }\end{array}$ & $\begin{array}{l}12 \text { EV-miRNAs were differentially } \\
\text { expressed between the normal and } \\
\text { failed to fertilize groups. } \\
\text { Hsa-miR-92a and miR-130b, were } \\
\text { over-expressed in FF samples from } \\
\text { oocytes that failed to fertilize } \\
\text { compared to those that were } \\
\text { normally fertilized. Hsa-miR- } 888 \\
\text { was over-expressed and miR-214 } \\
\text { and miR- } 454 \text { were underexpressed } \\
\text { in samples that resulted in } \\
\text { impaired day-3 embryo quality } \\
\text { compared to top-quality day-3 } \\
\text { embryos. }\end{array}$ & $8 / 14$ \\
\hline
\end{tabular}


Table 1. Cont.

\begin{tabular}{|c|c|c|c|c|c|c|c|c|}
\hline Reference & Location & Age (years) & Population Studied & Study Design & Outcome and Aim & $\begin{array}{c}\text { Analysis and } \\
\text { Normalization Methods }\end{array}$ & Principal Conclusion & Quality Score \\
\hline \multicolumn{9}{|c|}{ (B) Oocytes } \\
\hline $\begin{array}{l}\text { [33] (Barragán et } \\
\text { al., 2017) }\end{array}$ & Spain & $\begin{array}{c}\text { 1. Young } \\
\text { women with } \\
\text { high AFC (age } \\
21 \pm 1 \text { years and } \\
24 \pm 3 \text { follicles) } \\
\text { and low AFC } \\
\text { (age } 24 \pm 2 \text { years } \\
\text { and } 8 \pm 2 \\
\text { follicles); } 2 \text {. Old } \\
\text { women with } \\
\text { high AFC (age } \\
32 \pm 2 \text { years and } \\
29 \pm 7 \text { follicles) } \\
\text { and low AFC } \\
\text { (age } 34 \pm 1 \text { years } \\
\text { and } 7 \pm 1 \\
\text { follicles). }\end{array}$ & $\begin{array}{l}36 \text { in vivo matured MII } \\
\text { oocytes from } 30 \text { healthy } \\
\text { women recruited for } \\
\text { oocyte donation }\end{array}$ & Retrospective & $\begin{array}{l}\text { To identify the coding } \\
\text { and noncoding } \\
\text { transcriptional profiles of } \\
\text { in vivo matured MII } \\
\text { human oocytes and } \\
\text { evaluate their changes in } \\
\text { relation to age and, } \\
\text { independently, ovarian } \\
\text { reserve. }\end{array}$ & $\begin{array}{l}\text { Analysis: Microarray and } \\
\text { qRT-PCR validation. } \\
\text { Normalization: Actin B, } \\
\text { ubiquitin C and DNA } \\
\text { methyltransferase-1. }\end{array}$ & $\begin{array}{l}\text { A set of five miRNAs } \\
\text { (ENSG00000221162, hsa-miR-220b, } \\
\text { ENSG00000239174, miR-4262 and } \\
\text { 1260a) were increased in old group. }\end{array}$ & $7 / 14$ \\
\hline $\begin{array}{l}\text { [35] (Battaglia et } \\
\text { al., 2016) }\end{array}$ & Italy & $\begin{array}{l}\text { Young women } \\
\text { (28-35 years) } \\
\text { and old women } \\
\text { (38-40 years })\end{array}$ & $\begin{array}{l}\text { Six MII oocytes from } \\
\text { young women and six } \\
\text { from older women }\end{array}$ & Retrospective & $\begin{array}{l}\text { To identify human oocyte } \\
\text { miRNAs and } \\
\text { demonstrate } \\
\text { thatconditions altering } \\
\text { oocyte quality, such as } \\
\text { reproductive aging }\end{array}$ & $\begin{array}{c}\text { Analysis: qRT-PCR } \\
\text { screening and qRT-PCR } \\
\text { validation. } \\
\text { Normalization: RNU6B. }\end{array}$ & $\begin{array}{l}\text { Twelve miRNAs are differentially } \\
\text { expressed in women of advanced } \\
\text { reproductive age }\end{array}$ & $7 / 14$ \\
\hline $\begin{array}{l}\text { [34] (Xu et al., } \\
\text { 2011) }\end{array}$ & China & $\begin{array}{l}\text { 1. } 30.65 \pm 3.87 \\
\text { GV, and } 2.32 .15 \\
\quad \pm 4.63 \mathrm{MII} \\
\quad \text { oocytes }\end{array}$ & $\begin{array}{l}392 \text { oocytes at GV stage } \\
\text { and } 43 \text { oocytes at MI } \\
\text { stage during } 251 \text { ICSI } \\
\text { cycles }\end{array}$ & Retrospective & $\begin{array}{l}\text { To identify differentially } \\
\text { expressed miRNAs and } \\
\text { expression patterns of } \\
\text { specific miRNAs during } \\
\text { meiosis in human } \\
\text { oocytes. }\end{array}$ & $\begin{array}{l}\text { Analysis: Microarray and } \\
\text { qRT-PCR validation. } \\
\text { Normalization: U6 RNA }\end{array}$ & $\begin{array}{l}\text { Compared with GV oocytes, MII } \\
\text { oocytes exhibited up-regulation of } \\
4 \text { miRNAs (hsa-miR-193a-5p, 297, } \\
625 \text { and 602), and down-regulation } \\
\text { of } 11 \text { miRNAs (hsa-miR-888*, 212, } \\
662,299-5 \mathrm{p}, 339-5 \mathrm{p}, 20 \mathrm{2}, 486-5 \mathrm{p}, \\
141^{*}, 768-5 \mathrm{p}, 376 \mathrm{a} \text { and } 15 \mathrm{a} \text { ). }\end{array}$ & $7 / 14$ \\
\hline
\end{tabular}

Abbreviations: AFC, antral follicle count; COC, cumulus-oocyte complex; $\mathrm{CRC}$, corona radiata cells; DE-miRNAs, differentially expressed miRNAs; DOR, diminished ovarian reserve; EV, extracellular vesicles; FF, follicular fluid; GC, granulosa cells; GLC, granulosa lutein cells; GV, germinal vesicle; ICSI, intracytoplasmic sperm injection; IVF, in-vitro fertilization; MI, metaphase I; MII, metaphase II; ND, no data; NGS, next generation sequencing; NOR, normal ovarian reserve; OD, oocyte donors; PCOS, polycystic ovary syndrome; qRT-PCR, quantitative real-time PCR; RNAseq, RNA sequencing. 
Four of the 18 studies were conducted in fertile women and aimed at characterizing the normal miRNA expression patterns in human ovaries and exosomes (descriptive studies). Liang and collaborators, using qRT-PCR described a total of 216 miRNAs expressed in a healthy human ovary, with miR-26a being the most highly expressed in ovaries [9]. Although this was the first descriptive study, published results must be cautiously interpreted as they represent only a single ovary. Another study involving 20 women undergoing ICSI (some with PCOS) found 538 miRNAs in human follicular fluid (including miR-19b, miR-24, and miR-222). With a case-control approach analysis, the same study also discovered that the expression levels of miR-132 and miR-320 were significantly lower in controls $(n=22)$ than in PCOS $(n=22)$ patients [22]. Another study that evaluated follicular fluid exosomes isolated from 15 women undergoing ICSI found, using qRT-PCR, that 37 miRNAs were more highly expressed in human follicular fluid than in blood plasma and also identified 22 miRNAs that were exclusively present in the exosomes [23]. Finally, Tong and collaborators investigated, through NGS, the miRNA expression profiles of corona radiata (CRCs) and cumulus oophorus cells (COCs) in five women and identified a total of 785 and 799 miRNAs in CRCs and COCs, respectively. In addition, 72 DE-miRNAs were identified when comparing CRCs with COCs [24].

We identified two prospective studies aimed at comparing, through qRT-PCR, the expression of a set of ovarian miRNAs between older and younger women. The first work, which involved 16 women (young age: $<31$ years $(n=8)$ and advanced age: $>38$ years $(n=8))$, reported that miR-21-5p is present at significantly higher levels in the follicular fluid of younger women, and miR-99b-3p, miR-134 and miR-190b are found at significantly higher levels in the follicular fluid of older women [26]. The second work investigating follicular fluid miRNAs based on oocyte stage followed a more complex methodology that involved a two-stage analysis: 1$)$ younger group: $<35(n=15)$ vs. older group: $>37$ $(n=15)$, and 2$)$ metaphase II (MII) vs. germinal vesicle (GV) $(n=12)$, and metaphase I (MI) vs. MII $(n=9)$; each patient acted as her own control. In this case, miR-424 was found to be highly expressed in the follicular fluid of patients with advanced age. Moreover, 13 DE-miRNAs were identified in the follicular fluid of MII- vs. GV-oocytes, and seven DE-miRNAs were detected when MI- and MII-oocytes were compared [32].

Only one cross-sectional study could be included in this review. In that study, using qRT-PCR, the authors investigated miRNA content of follicular fluid microvesicles isolated from follicles corresponding to oocytes with normal fertilization $(n=93)$ compared with those corresponding to oocytes that failed to fertilize $(n=33)$. These authors found 12 DE-miRNAs between normal and failed-to-fertilize groups. MiR-92a and miR-130b were over-expressed in follicular fluid microvesicles associated with oocytes that failed to fertilize compared to those that were normally fertilized. Interestingly, miR-888 was over-expressed and miR-214 and miR-454 were under-expressed in samples that resulted in low quality compared to top-quality day-3 embryos [31].

Eleven case-control studies were included in this systematic review. Of those that were included, two different groups of articles were identified: 1) studies focused on the miRNAs expressed in patients with PCOS; and 2) studies with poor responder patients, diminished ovarian reserve (DOR) or no blastocyst formation.

Eight studies focused on the miRNAs expressed in patients with polycystic ovary syndrome (PCOS) were identified. Four out of the eight works were designed as high-throughput studies (two used NGS plus validation with qRT-PCR and two used qRT-PCR only). Luo et al., 2019 [30] published a very recent article comparing the miRNA expressed in granulosa cells (GC) of poor ovarian response $(n=7)$ and of PCOS patients $(n=20)$ with those found in control individuals $(n=18)$. They identified 20 conserved and three novel miRNAs that were upregulated in the poor ovarian response group, and 30 conserved miRNAs and one novel miRNA that were up-regulated in the PCOS group [30]. In a similar GC-based study, Xu et al., 2015 [21] compared, through NGS, 21 women presenting PCOS with 20 women without PCOS (control). These authors identified 59 known DE-miRNAs in PCOS patients; 21 miRNAs were up-regulated and 38 miRNAs were down-regulated in PCOS patients [21]. In another work, Roth et al., 2014 [17] compared, through qRT-PCR, the miRNAs from follicular fluid of 
10 PCOS patients with that of 10 oocyte donors and discovered 29 DE-miRNAs in PCOS patients. In the validation step, only the levels of five of ten validated miRNAs (miR-9, miR-18b, miR-32, miR-34c, and miR-135a) were significantly higher in PCOS patients compared with oocyte donors [17]. Finally, the fourth study evaluated the miRNAs expressed in COCs from 24 PCOS patients and 24 controls, and found that the levels of miR-483-5p and miR-486-5p were significantly lower in PCOS than in non-PCOS patients [19].

The other four articles explored a small number of miRNAs in PCOS patients, all using qRT-PCR. One of these studies compared the expression of five miRNAs in the follicular fluid between 30 women with PCOS and 91 women with normal ovarian reserve (NOR; as controls), and found that miR-30a was significantly up-regulated and miR-140 and let- $7 \mathrm{~b}$ were significantly down-regulated in the follicular fluid from patients with PCOS compared with women with NOR [18]. Another work investigated, by comparing women suffering from PCOS $(n=25)$ with women without PCOS $(n=20)$, the effects of miR-145 on cell proliferation and its underlying mechanism in isolated human granulosa cells from aspirated follicular fluid. In this study, miR-145 was found to be down-regulated in PCOS compared to control subjects [16]. In the third study, Eisenberg et al., 2017 [27] evaluated the expression of miR-200b and miR-429 in granulosa cells of 15 normally ovulating women (fertile women) suffering infertility due purely to male infertility factors (infertile men), 18 women with PCOS and seven normally ovulating women. The authors discovered very low expression of both miRNAs in granulosa cells of all patients, with miR-200b expression being relatively higher than miR-429 [27]. In the fourth study, Wang and collaborators measured the expression of miRNAs in the granulosa cells of PCOS patients $(n=17)$ and 17 healthy controls. They identified 21 miRNAs up-regulated and 38 down-regulated in the granulosa cells of PCOS compared to those of healthy patients. Remarkably, the expression of miR-27a-3p was found to be significantly increased in both granulosa cells and ovaries of patients with PCOS compared to healthy controls [20].

In studies with poor responder patients, diminished ovarian reserve (DOR), or no blastocyst formation, three articles were selected. In these three studies, different techniques were used (NGS, microarrays, and qRT-PCR). In the first selected article, Chen et al., 2017 [25] used NGS to compare miRNA expression in the COCs of 10 women with DOR and 10 women with NOR. Seventy-nine annotated miRNAs and five novel miRNAs were found to be differentially expressed between DOR and NOR [25]. In the second work, Karakaya et al., 2015 [29] compared the miRNA expression in COCs of 24 poor ovarian hyperstimulation responders with that of 32 normal responders (controls). They identified 16 miRNAs up-regulated and 88 down-regulated in poor responders (microarray analysis), and validated by qRT-PCR the increased expression of miR-21-5p and the reduced expression of miR-21-3p in poor responders. [29]. Finally, Fu et al., 2018 [28] used qRT-PCR to compare the expression of miRNAs in the follicular fluid in 53 cases that yielded no blastocysts on day-five and 38 controls with viable blastocysts (higher than $3 \mathrm{BC} / 3 \mathrm{CB}$ ). They observed 13 up-regulated miRNAs and three down-regulated miRNAs in cases (i.e., no blastocyst development) compared with controls. It is worth noting that miR-663b expression was found to be significantly higher in cases than in controls in the validation [28].

\subsubsection{Oocytes}

Only three retrospective oocyte studies using microarray screening and qRT-PCR validation were included in this systematic review (Table 1-B). The quality scores of these retrospective studies are $7 / 14$ (mean).

With the objective to identify DE-miRNAs and expression patterns of specific miRNAs during meiosis in human oocytes, $\mathrm{Xu}$ and collaborators [34] used $392 \mathrm{GV}$-oocytes and 43 MII-oocytes in a study that involved 251 ICSI cycles. The authors observed that, compared to GV-oocytes, the MII counterparts exhibited an up-regulation of four miRNAs (miR-193a-5p, miR-297, miR-625, and miR-602), and a down-regulation of 11 miRNAs (miR-888*, miR-212, miR-662, miR-299-5p, miR-339-5p, miR-20a, miR-486-5p, miR-141*, miR-768-5p, miR-376a, and miR-15a) [34]. The other work used 36 in vivo 
matured MII-oocytes from 30 healthy women recruited for oocyte donation and evaluated whether miRNA expression varies with women's age and ovarian reserve. The study revealed a set of five miRNAs (ENSG00000221162, miR-220b, ENSG00000239174, miR-4262, and miR-1260a) that were more highly expressed in the old than in the young age group, regardless of the ovarian reserve [33]. Finally, Battaglia et al., with the aim to identify whether aging can alter the expression of miRNAs in human oocytes, found that 12 miRNAs were differentially expressed in women of advanced reproductive age (e.g., let-7b, let-7e, miR-19a, miR-29a, miR-126, miR-136, miR-192, miR-203, miR-371a-3p, miR-484, miR-494, and miR-519d) [35].

\subsubsection{Embryos}

Table 2 summarizes the embryo studies included in this systematic review. The quality scores are the following: case-control studies mean $=5.8 / 12$, and prospective studies mean $=7 / 14$.

Only two prospective studies were included in this systematic review. These works aimed at determining whether human blastocysts secrete miRNAs into culture media and whether these secreted miRNAs reflect the embryonic ploidy status and are predictive of IVF outcomes. First, evaluating miRNA isolated from spent culture media from 28 tested blastocysts (SBM), Rosenbluth and collaborators identified, through qRT-PCR, 10 miRNAs (miR-106b, miR-191, miR-30c, miR-372, miR-376a, miR-548a-3p, miR-548c-3p, miR-548d-3p, miR-576d-3p, and miR-603) consistently expressed in the culture media (miR-372 and miR-191 confirmed by single assay). These authors also found that levels of miR-191 were higher in media from aneuploid embryos, and miR-191, miR-372, and miR-645 were more highly concentrated in day-five media from embryos corresponding to failed IVF cycles [42]. The second study used trophectoderm (TE) samples and their corresponding SBM from five good-quality human blastocysts with qRT-PCR screening and subsequent validation [41]. In that case, the comparative analysis of TE and SBM samples revealed that $96.6 \%$ (57 of 59) of the miRNAs detected in the SBM were expressed in TE cells. miRNA analysis of SBM from euploid implanted and non-implanted blastocysts found that expression of two miRNAs (miR-20a and miR-30c) was higher in the former than in the latter [41].

Five case-control studies were included in this systematic review. The first two articles used embryonic tissues (mostly trophoblast) from patients suffering from tubal ectopic pregnancy (EP) and voluntary termination of pregnancy (VTOP; controlled abortion). One of these studies was designed as a screening study (microarray and qRT-PCR validation) with 23 EP cases and 29 VTOP controls and found four miRNAs (miR-196b, miR-30a, miR-873, and miR-337-3p) were down-regulated in EP vs. control samples, and three miRNAs (miR-1288, miR-451, and miR-223) were up-regulated in EP compared to control samples (validation confirmed the DE-miRNAs miR-196 and miR-223) [36]. The second study explored LIN28/let-7 system in 17 EP patients and 23 VTOP controls. They observed that LIN28b mRNA was barely detectable in embryonic tissue from early stages of gestation and increased thereafter at seven to nine weeks of gestation. In contrast, expression levels of let-7, miR-132, and miR-145 were high in embryonic tissues from early gestations ( $\leq 6$-weeks) and abruptly declined thereafter, especially for let-7 (opposite trends for miR-323-3p). Embryonic expression of LIN28b mRNA was higher at early stages ( $\leq 6$-weeks) of EP than in normal gestation. In contrast, let-7a expression was significantly lower in early EP, whereas miR-132 and miR-145 levels were not altered (miR-323-3p expression was also suppressed in ectopic embryonic tissue) [40]. 
Table 2. Summary of the studies in embryonic tissues.

\begin{tabular}{|c|c|c|c|c|c|c|c|c|}
\hline Reference & Location & Age (years) & $\begin{array}{l}\text { Population } \\
\text { Studied }\end{array}$ & Study Design & $\begin{array}{c}\text { Outcome and } \\
\text { Aim }\end{array}$ & $\begin{array}{l}\text { Analysis and } \\
\text { Normalization } \\
\text { Methods }\end{array}$ & Principal Conclusion & Quality Score \\
\hline $\begin{array}{c}\text { [41] (Capalbo et } \\
\text { al., 2016) }\end{array}$ & Italy & ND & $\begin{array}{c}\text { ICM-free TE } \\
\text { samples and } \\
\text { their relative } \\
\text { SBM from } 5 \\
\text { good-quality } \\
\text { human } \\
\text { blastocysts }\end{array}$ & Prospective & $\begin{array}{l}\text { To identify } \\
\text { miRNAs } \\
\text { secreted by } \\
\text { human embryos } \\
\text { in culture } \\
\text { media, which } \\
\text { can be used as } \\
\text { biomarkers of } \\
\text { embryo quality } \\
\text { during IVF } \\
\text { cycles. }\end{array}$ & $\begin{array}{l}\text { Analysis: } \\
\text { qRT-PCR } \\
\text { screening and } \\
\text { qRT-PCR } \\
\text { validation. } \\
\text { Normalization: } \\
\text { RNU44 and } \\
\text { RNU48. }\end{array}$ & $\begin{array}{l}\text { The comparative analysis of TE } \\
\text { and SBM samples revealed that } \\
\text { 96.6\% (57/59) of the miRNAs } \\
\text { detected in the SBM were derived } \\
\text { from TE cells. MiRNAs analysis of } \\
\text { SBM from euploid implanted and } \\
\text { unimplanted blastocysts } \\
\text { highlighted two miRNAs } \\
\text { (hsa-miR-20a and 30c) that showed } \\
\text { increased concentrations in the } \\
\text { former. }\end{array}$ & $7 / 14$ \\
\hline $\begin{array}{l}\text { [42] (Rosenbluth } \\
\text { et al., 2014) }\end{array}$ & USA & ND & $\begin{array}{l}28 \text { tested } \\
\text { blastocysts SBM, } \\
\text { from } 13 \text { couples }\end{array}$ & Prospective & $\begin{array}{l}\text { To determine } \\
\text { whether human } \\
\text { blastocysts } \\
\text { secrete miRNAs } \\
\text { into culture } \\
\text { media and } \\
\text { whether these } \\
\text { reflect } \\
\text { embryonic } \\
\text { ploidy status } \\
\text { and can predict } \\
\text { IVF outcomes. }\end{array}$ & $\begin{array}{l}\text { Analysis: } \\
\text { qRT-PCR } \\
\text { screening and } \\
\text { qRT-PCR } \\
\text { validation. } \\
\text { Normalization: } \\
\text { U6. }\end{array}$ & $\begin{array}{c}\text { Ten miRNAs (hsa-miR-106b, 191, } \\
\text { 30c, 372, 376a, 548a-3p, 548c-3p, } \\
\text { 548d-3p, 576d-3p, and 603) were } \\
\text { consistently detected in the spent } \\
\text { IVF culture media, but only two } \\
\text { miRNAs (hsa-miR-372 and 191) } \\
\text { were confirmed by later single } \\
\text { assay qRT-PCR. Hsa-miR-191 was } \\
\text { more highly concentrated in media } \\
\text { from aneuploid embryos, } \\
\text { and hsa-miR-191, 372, and } 645 \\
\text { were more highly concentrated in } \\
\text { media from failed } \\
\text { IVF/non-intracytoplasmic sperm } \\
\text { injection cycles. }\end{array}$ & $7 / 14$ \\
\hline $\begin{array}{c}{[36]} \\
\text { (Dominguez et } \\
\text { al., 2014) }\end{array}$ & Spain & $\begin{array}{c}\text { Screening: EP: } \\
30.75 \pm 1.78 \\
\text { VTOP: } 26 \pm 3.17 . \\
\text { Validation: EP: } \\
30.81 \pm 1.55 \\
\text { VTOP: } 24.62 \pm \\
1.86 .\end{array}$ & $\begin{array}{l}\text { Cases: } 23 \\
\text { patients } \\
\text { suffering from } \\
\text { tubal EP ( } 8 \text { in } \\
\text { screening and } \\
15 \text { in validation). } \\
\text { Controls: } 29 \\
\text { patients with } \\
\text { VTOP ( } 8 \text { in } \\
\text { screening and } 21 \\
\text { in validation). }\end{array}$ & Case-control & $\begin{array}{l}\text { To investigate } \\
\text { the miRNA } \\
\text { profile of } \\
\text { embryonic } \\
\text { tissues in EP } \\
\text { and controlled } \\
\text { abortions VTOP }\end{array}$ & $\begin{array}{l}\text { Analysis: } \\
\text { Microarray } \\
\text { screening and } \\
\text { qRT-PCR } \\
\text { validation. } \\
\text { Normalization: } \\
\text { SNORD96A. }\end{array}$ & $\begin{array}{l}\text { Four miRNAs (hsa-miR-196b, 30a, } \\
\text { 873, and 337-3p) were found to be } \\
\text { downregulated in EP versus } \\
\text { healthy pregnancy tissues, } \\
\text { and three miRNAs (hsa-miR-1288, } \\
\text { 451, and 223) were upregulated in } \\
\text { EP compared to control pregnancy } \\
\text { tissue samples. Validation } \\
\text { confirmed the differentially } \\
\text { expression of the miRNAs } \\
\text { hsa-miR-196 and } 223 \text {. }\end{array}$ & $7 / 12$ \\
\hline
\end{tabular}


Table 2. Cont.

\begin{tabular}{|c|c|c|c|c|c|c|c|c|}
\hline Reference & Location & Age (years) & $\begin{array}{l}\text { Population } \\
\text { Studied }\end{array}$ & Study Design & $\begin{array}{c}\text { Outcome and } \\
\text { Aim }\end{array}$ & $\begin{array}{l}\text { Analysis and } \\
\text { Normalization } \\
\text { Methods }\end{array}$ & Principal Conclusion & Quality Score \\
\hline $\begin{array}{l}\text { [40] (Lozoya et } \\
\text { al., 2014) }\end{array}$ & Spain & $\begin{array}{c}\text { EP: } 30.9, \text { VTOP: } \\
21.1\end{array}$ & $\begin{array}{c}\text { Cases: } 17 \\
\text { patients } \\
\text { suffering from } \\
\text { tubal EP. } \\
\text { Controls: } 23 \\
\text { patients with } \\
\text { VTOP. }\end{array}$ & Case-control & $\begin{array}{l}\text { To determine } \\
\text { the expression } \\
\text { of the elements } \\
\text { of the } \\
\text { Lin28/Let-7 } \\
\text { system, } \\
\text { and related } \\
\text { miRNAs in } \\
\text { early stages of } \\
\text { human } \\
\text { placentation } \\
\text { and ectopic } \\
\text { pregnancy }\end{array}$ & $\begin{array}{l}\text { Analysis: } \\
\text { qRT-PCR. } \\
\text { Normalization: } \\
\text { RNU6. }\end{array}$ & $\begin{array}{l}\text { LIN28B mRNA was barely } \\
\text { detectable in embryonic tissue } \\
\text { from early stages of gestation and } \\
\text { sharply increased thereafter to } \\
\text { plateau between gestational weeks } \\
\text { 7-9. In contrast, expression levels } \\
\text { of Let-7, mir-132 and mir-145 were } \\
\text { high in embryonic tissue from } \\
\text { early gestations ( } \leq 6 \text {-weeks) and } \\
\text { abruptly declined thereafter, } \\
\text { especially for Let-7. Opposite } \\
\text { trends were detected for } \\
\text { mir-323-3p. Embryonic expression } \\
\text { of LIN28B mRNA was higher in } \\
\text { early stages ( } \leq 6 \text {-weeks) of ectopic } \\
\text { pregnancy than in normal } \\
\text { gestation. In contrast, Let-7a } \\
\text { expression was significantly lower } \\
\text { in early ectopic pregnancies, while } \\
\text { miR-132 and miR-145 levels were } \\
\text { not altered. Expression of } \\
\text { mir-323-3p was also suppressed in } \\
\text { ectopic embryonic tissue. }\end{array}$ & $6 / 12$ \\
\hline $\begin{array}{c}\text { [37] (McCallie et } \\
\text { al., 2010) }\end{array}$ & USA & ND & $\begin{array}{l}\text { Cryopreserved } \\
\text { blastocysts } \\
(n=22) \text {. Cases: } \\
\text { blastocysts from } \\
\text { MF infertility } \\
\text { alone }(n=6), \\
\text { and blastocysts } \\
\text { from PCOS } \\
\text { women }(n=6) \text {. } \\
\text { Controls: } \\
\text { Oocyte donor } \\
\text { cycles with no } \\
\text { known MF } \\
\text { infertility } \\
(n=10)\end{array}$ & Case-control & $\begin{array}{l}\text { To examine } \\
\text { human } \\
\text { blastocyst } \\
\text { miRNA } \\
\text { expression (11 } \\
\text { probes) in } \\
\text { correlation with } \\
\text { human } \\
\text { infertility. }\end{array}$ & $\begin{array}{l}\text { Analysis: } \\
\text { qRT-PCR. } \\
\text { Normalization: } \\
\text { RNU48. }\end{array}$ & $\begin{array}{l}\text { Morphologically similar } \\
\text { blastocysts derived from patients } \\
\text { with PCOS or MF infertility } \\
\text { exhibited a significant decrease in } \\
\text { the expression of six miRNAs } \\
\text { (hsa-let-7a, miR-19a, 19b, } 24,93 \\
\text { and 94) in comparison with donor } \\
\text { fertile control blastocysts. } \\
\text { Annotation of predicted gene } \\
\text { targets for these DE-miRNAs } \\
\text { included gene ontology biological } \\
\text { processes involved in cell growth } \\
\text { and maintenance and } \\
\text { transcription. }\end{array}$ & $6 / 12$ \\
\hline
\end{tabular}


Table 2. Cont.

\begin{tabular}{|c|c|c|c|c|c|c|c|c|}
\hline Reference & Location & Age (years) & $\begin{array}{l}\text { Population } \\
\text { Studied }\end{array}$ & Study Design & $\begin{array}{c}\text { Outcome and } \\
\text { Aim }\end{array}$ & $\begin{array}{l}\text { Analysis and } \\
\text { Normalization } \\
\text { Methods }\end{array}$ & Principal Conclusion & Quality Score \\
\hline $\begin{array}{c}\text { [39] (McCallie et } \\
\text { al., 2014) }\end{array}$ & USA & $\begin{array}{l}\text { Chromosomally } \\
\text { normal } \\
\text { blastocystsfrom } \\
\text { young, OD }(26.4 \\
\text { years) } \\
\text { Chromosomallynormal } \\
\text { blastocysts from } \\
\text { women in their forties } \\
\text { (40-44 years) }\end{array}$ & $\begin{array}{l}\text { Cases: } \\
\text { blastocysts } \\
\text { produced from } \\
\text { women in their } \\
\text { forties }(n=5) \text {. } \\
\text { Controls: young } \\
\text { oocyte donor } \\
\text { derived } \\
\text { blastocysts } \\
(n=5)\end{array}$ & Case-control & $\begin{array}{c}\text { To determine } \\
\text { miRNA } \\
\text { expression in } \\
\text { human } \\
\text { blastocysts } \\
\text { relative to } \\
\text { advanced } \\
\text { maternal age } \\
\text { and } \\
\text { chromosome } \\
\text { constitution. }\end{array}$ & $\begin{array}{l}\text { Analysis: } \\
\text { qRT-PCR. } \\
\text { Normalization: } \\
\text { MammU6. }\end{array}$ & $\begin{array}{l}42 \text { DE-miRNAs. miR-93 was } \\
\text { exclusively expressed in } \\
\text { blastocysts from women in their } \\
\text { forties and further up-regulated } \\
\text { with an abnormal chromosome } \\
\text { complement. Up-regulated miR-93 } \\
\text { resulted in an inverse } \\
\text { down-regulation of targets like } \\
\text { SIRT1, resulting in reduced } \\
\text { oxidative defense. }\end{array}$ & $5 / 12$ \\
\hline $\begin{array}{l}\text { [38] (Rosenbluth } \\
\text { et al., 2013) }\end{array}$ & USA & ND & $\begin{array}{c}\text { Screening } \\
\text { (Cases: } 5 \\
\text { aneuploids. } \\
\text { Controls: } 4 \\
\text { male, } 5 \text { females } \\
\text { euploid.). } \\
\text { Validation } \\
\text { (Cases: } 9 \\
\text { aneuploids. } \\
\text { Controls: } 7 \\
\text { male, } 11 \text { females } \\
\text { euploid.). }\end{array}$ & $\begin{array}{c}\text { Case-control } \\
\text { and Descriptive }\end{array}$ & $\begin{array}{l}\text { To determine } \\
\text { the most highly } \\
\text { expressed } \\
\text { miRNAs in } \\
\text { human } \\
\text { blastocysts and } \\
\text { to compare } \\
\text { miRNAs in } \\
\text { euploid versus } \\
\text { aneuploid } \\
\text { embryos and in } \\
\text { male versus } \\
\text { female embryos. }\end{array}$ & $\begin{array}{l}\text { Analysis: } \\
\text { qRT-PCR } \\
\text { screening and } \\
\text { qRT-PCR } \\
\text { validation. } \\
\text { Normalization: } \\
\text { snRNA U6. }\end{array}$ & $\begin{array}{l}\text { The most highly expressed miRNA } \\
\text { in euploid embryos was miR-372. } \\
\text { Screening identified } 39 \text { miRNAs } \\
\text { that were differentially expressed } \\
\text { between euploid }(n=9) \text { and } \\
\text { aneuploid }(n=5) \text { embryos, and } 21 \\
\text { miRNAs that were differentially } \\
\text { expressed between male }(n=4) \\
\text { and female }(n=5) \text {. }\end{array}$ & $\begin{array}{c}\text { Case-control: } \\
5 / 12 . \\
\text { Descriptive: } 6 / 9 .\end{array}$ \\
\hline
\end{tabular}

Abbreviations: DE-miRNAs, differentially expressed miRNAs; EP, ectopic pregnancies; ICM, inner cell mass; IVF, in vitro fertilization; MF, male factor; ND, no data; OD, oocyte donors;

PCOS, polycystic ovary syndrome; qRT-PCR, quantitative real-time PCR; SBM, spent blastocyst culture media; TE, trophectoderm; VTOP, voluntary termination of pregnancy. 
The first article that was published with the aim to examine whether the miRNA expression profile in human blastocysts is correlated with infertility was produced by McCallie et al. (2010) [37]. Evaluating cryopreserved blastocysts with male factor infertility alone $(n=6)$, blastocysts from women with PCOS $(n=6)$, and blastocysts from donor oocyte cycles with no known male factory infertility $(n=10)$, these authors found, through qRT-PCR, that blastocysts derived from PCOS and from infertile males exhibiting significantly lower expression of six miRNAs (let-7a, miR-19a, miR-19b, miR-24, miR-93, and miR-94) than fertile controls [37]. Some years later, the same research group utilized a high-throughput strategy and compared blastocysts produced from women in their forties $(n=5)$ with those derived from young (mean 26.4 years) oocyte donors $(n=5)$. Forty-two DE-miRNAs were identified, with miR-93 being exclusively expressed in blastocysts from women in their forties and up-regulated in aneuploid blastocysts [39].

Finally, Rosenbluth et al., 2013 [38] designed the most comprehensive study to date to identify the most highly expressed miRNAs in human blastocysts. They compared miRNAs expressed in euploid vs. aneuploid embryos, and in male vs. female embryos. They found that the most highly expressed miRNA in euploid embryos was miR-372 and identified 39 miRNAs that were differentially expressed between euploid $(n=9)$ and aneuploid $(n=5)$ embryos, and 21 miRNAs that were differentially expressed between male $(n=4)$ and female $(n=5)$ euploid embryos [38].

\section{Discussion}

To the extent of our knowledge, we have conducted the most comprehensive analysis to date of descriptive and observational studies describing the miRNA content in reproductive female cells/tissues and embryos and the primary associations between miRNA expression and the risk of infertility and compromised early embryo development. On the basis of the results of the present analysis, these data strongly suggest that the presence and expression levels of miRNAs in the aforementioned cells/tissues are related with female fertility and embryo development. These evidences indicate that measuring the expression of particular miRNAs, particularly in exosomes, microvesicles, or in embryo media, might be useful as biomarkers of infertility and may be prognostic of embryo development potential. Increased understanding of the function of these miRNAs may also provide some clues to improve IVF/ICSI protocols and embryo culture.

\subsection{Highly Expressed miRNAs in Female Reproductive Cells/Tissues and Embryos}

Figure 2 shows the most abundantly expressed miRNAs in ovaries, extracellular vesicles (exosomes and microvesicles) and embryos (note that no descriptive studies were found in oocytes). Among the highly expressed miRNAs, three of them are constantly present in ovaries or extracellular vesicles and embryos suggesting a maternal line inheritance.

The hsa-miR-191-5p deserves special attention. The encoding region of this miRNA is located on chromosome 3 (3p21.31) is highly expressed in ovaries and embryos, and seems to play an important role in cell cycle regulation [43]. Moreover, very recently, Cook et al. described that this miRNA, in conjunction with eight others, may serve as a new circulating biomarker of preterm birth [44], which would indicate that it is essential in the tissues analyzed. On the other hand, hsa-miR-202-3p (situated in chromosome 10, q26.3) is interesting because it has been found to play a role in the first and second trimester placenta and fetal growth in two independent studies $[45,46]$. However, more efforts with this miRNA are required because both reports are relatively small pilot studies. Finally, another remarkable miRNA is hsa-miR-320a (located on chromosome 8, p21.3). This miRNA is highly expressed in ovaries and embryos as well as in epididymis and spermatozoa, suggesting an essential role in both male and female reproductive processes [47]. Mouse knockdowns of this miRNA caused decreased proportions of MII oocytes that developed into two-cell and blastocyst stage embryos [48]. Other authors suggested that miR-320a contributed to ovarian development by targeting KITLG [49]. 
A

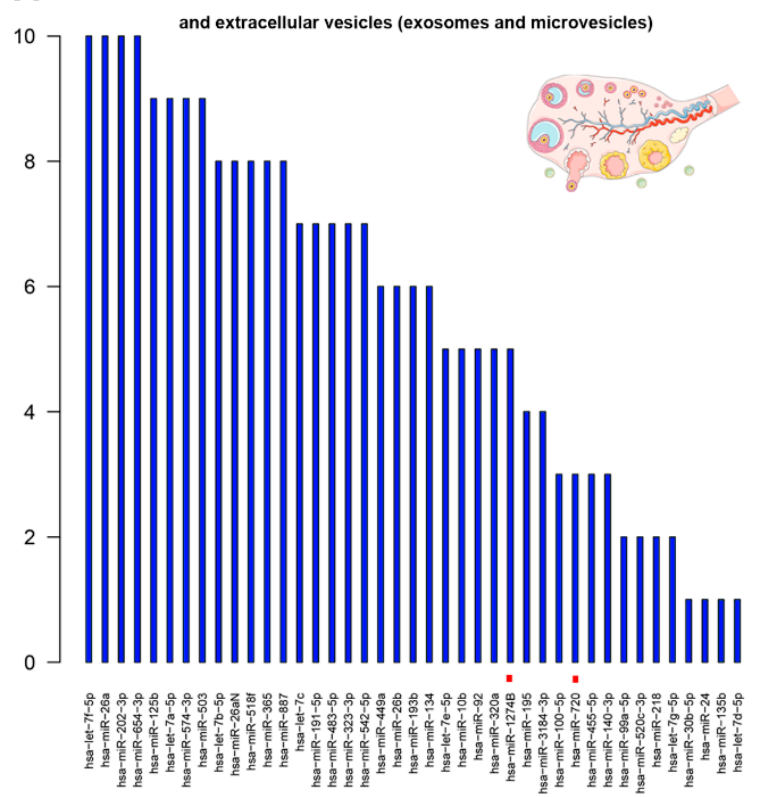

B Embryo

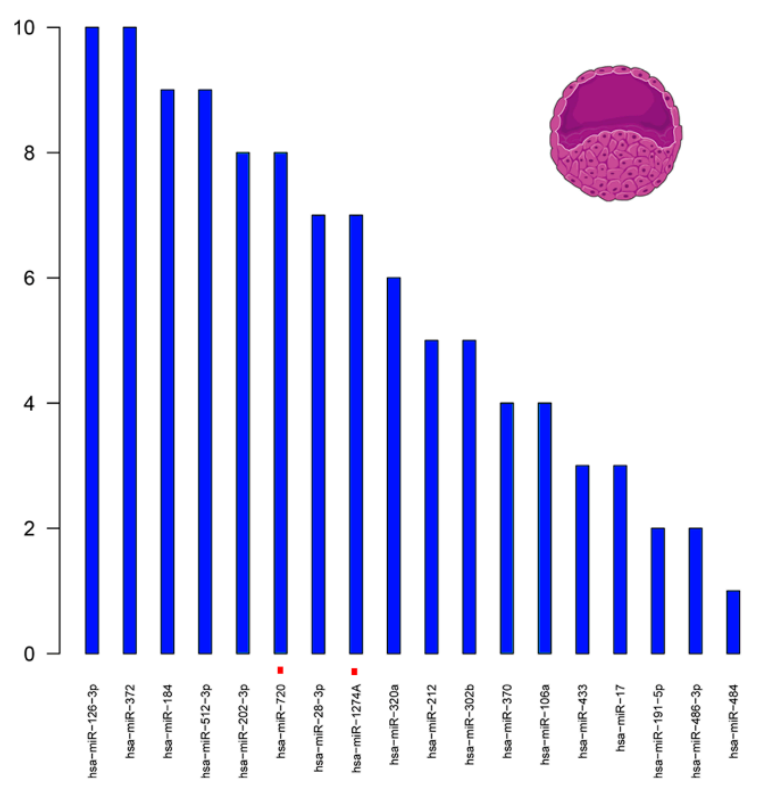

Figure 2. Top expressed miRNAs in human (A) ovaries (and/or extracellular vesicles) and (B) embryos. Notes: With the information about the top 10 miRNAs detected in every descriptive study we have scored each of the top 10 miRNAs with an arbitrary number (10; the most expressed to 1; the least expressed). The average score was then calculated for each miRNA to create the final list of most highly expressed miRNAs in every tissue/cell type. The miRNAs with potentially equivocal codes were recoded according to miRBase v.22.1 (http://www.mirbase.org/) information. Red dots mean that the miRNA was removed from the miRBase database (not a confirmed miRNA): hsa-miR-720 is a fragment of a tRNA; hsa-miR-1274A is a fragment of fragment of a Lys tRNA; and hsa-miR-1274B is a fragment of fragment of a Lys tRNA.

\section{2. miRNA Deregulations as a Risk of Infertility or Embryo Development Errors}

Taking into account the top miRNAs identified as DE-miRNAs (Supplemental Table S2) between fertile and infertile women or different embryo types, we propose a list of DE-miRNAs (hsa-miR-9, -21, $-27 b,-29 b,-30 a,-146 a,-150,-339-3 p,-424,-451,-663 b$, and -1275 ; Table 3) that can play a central role in female reproductive physiology and embryogenesis.

Although the majority of the aforementioned miRNAs (in Table 3) have a clear association with different cancers and their progression (https://pathcards.genecards.org/card/micrornas_in_cancer), some of these miRNAs also have other functions beyond female fertility. For example, miR-9 has a potential target gene called TIMP3 that is involved in testis development and differentiation [50]. Another interesting miRNA is miRNA-30a. The miR-30 family, which includes miR-30a, -30b and -30c, has been extensively studied in Danio rerio and is associated with the hedgehog pathway, closely related to embryo development [51]. Finally, the inhibition of miR-424 in mice (miR-322 in mice) confirmed the key role of this miRNA in sperm DNA damage during spermatogenesis [52]. 
Table 3. Primary differentially expressed miRNAs that can play a central role in female reproductive physiology and embryology.

\begin{tabular}{|c|c|c|c|c|}
\hline miRNA Name & miRBase Accession Number & Tissue/Cell Expressed & DE-miRNA Condition(s) & Main Publication(s) \\
\hline hsa-miR-9 & MIMAT0000441 & $\begin{array}{l}\text { 1. Granulosa cells } \\
\text { 2. Follicular fluid }\end{array}$ & $\begin{array}{l}\text { 1. PCOS vs. oocyte donors } \\
\text { 2. PCOS vs. oocyte donors }\end{array}$ & {$[17,30]$} \\
\hline hsa-miR-21 & MIMAT0000076 & $\begin{array}{l}\text { 1. Granulosa cells } \\
\text { 2. Cumulus cells } \\
\text { 3. Follicular fluid }\end{array}$ & $\begin{array}{l}\text { 1. PCOS vs. oocyte donors } \\
\text { 2. Poor-responders vs. non-poor responders } \\
\text { 3. Older vs. younger women }\end{array}$ & {$[26,29,30]$} \\
\hline hsa-miR-27b & MIMAT0000419 & $\begin{array}{l}\text { 1. Follicular fluid } \\
\text { 2. Cumulus cells } \\
\text { 3. Blastocysts }\end{array}$ & $\begin{array}{l}\text { 1. MII vs. GV } \\
\text { 2. Poor-responders vs. non-poor responders } \\
\text { 3. Aneuploid vs. euploid }\end{array}$ & {$[29,32,38]$} \\
\hline hsa-miR-29b & MIMAT0000100 & Follicular fluid & MII vs. GV and MII vs. MI & [32] \\
\hline hsa-miR-30a & MIMAT0000087 & $\begin{array}{l}\text { 1. Follicular fluid } \\
\text { 2. Embryonic tissue }\end{array}$ & $\begin{array}{l}\text { 1. PCOS vs. oocyte donors } \\
\text { 2. EP vs. VTOP }\end{array}$ & {$[18,36]$} \\
\hline hsa-miR-146a & MIMAT0000449 & Granulosa cells & $\begin{array}{l}\text { PCOS vs. oocyte donors and Poor ovarian response vs. } \\
\text { oocyte donors }\end{array}$ & {$[30]$} \\
\hline hsa-miR-150 & MIMAT0000451 & $\begin{array}{l}\text { 1. Follicular fluid } \\
\text { 2. Cumulus cells }\end{array}$ & $\begin{array}{l}\text { 1. Non-viable vs. viable blastocysts } \\
\text { 2. Poor-responders vs. non-poor responders }\end{array}$ & {$[28,29]$} \\
\hline hsa-miR-339-3p & MIMAT0004702 & $\begin{array}{l}\text { 1. Follicular fluid } \\
\text { 2. Blastocysts }\end{array}$ & $\begin{array}{l}\text { 1. MII vs. GV } \\
\text { 2. Aneuploid vs. euploid }\end{array}$ & {$[32,38]$} \\
\hline hsa-miR-424 & MIMAT0001341 & $\begin{array}{l}\text { 1. Follicular fluid } \\
\text { 2. Cumulus cells } \\
\text { 3. Follicular fluid }\end{array}$ & $\begin{array}{l}\text { 1. Non-viable vs. viable blastocysts } \\
\text { 2. Poor-responders vs. non-poor responders } \\
\text { 3. Older vs. younger women }\end{array}$ & {$[28,29,32]$} \\
\hline $\begin{array}{l}\text { hsa-miR-451 } \\
\text { miRNA Name }\end{array}$ & $\begin{array}{c}\text { MIMAT0001631 } \\
\text { miRBase Accession Number }\end{array}$ & $\begin{array}{l}\text { 1. Follicular fluid } \\
\text { 2. Embryonic tissue } \\
\text { Tissue/Cell Expressed }\end{array}$ & $\begin{array}{l}\text { 1. MII vs. GV and MII vs. MI } \\
\text { 2. EP vs. VTOP } \\
\text { DE-miRNA Condition(s) }\end{array}$ & $\begin{array}{c}{[32,36]} \\
\text { Main Publication(s) }\end{array}$ \\
\hline hsa-miR-663b & MIMAT0005867 & $\begin{array}{l}\text { 1. Follicular fluid } \\
\text { 2. Cumulus cells }\end{array}$ & $\begin{array}{l}\text { 1. Non-viable vs. viable blastocysts } \\
\text { 2. Poor-responders vs. non-poor responders }\end{array}$ & {$[28,29]$} \\
\hline hsa-miR-1275 & MIMAT0005929 & $\begin{array}{l}\text { 1. Cumulus cells } \\
\text { 2. Granulosa cells }\end{array}$ & $\begin{array}{l}\text { 1. DOR vs. NOR } \\
\text { 2. PCOS vs. oocyte donors }\end{array}$ & {$[21,25]$} \\
\hline
\end{tabular}




\subsection{Looking Beyond the Present Systematic Review}

In the present systematic review, studies dealing with gestational or specific female sexual tract tissues (e.g., fallopian tubes or endometrial tissue) were excluded in order to focus on the expression of miRNAs in ovaries and/or extracellular vesicles, oocytes, and embryos. We encourage the scientific community consider the aforementioned tissues to compliment the conclusions of this systematic review. For example, an interesting study by Ferlita et al. discussed the function of non-coding RNAs (including miRNAs) in endometrial physiology, analyzing their role in endometrial pathologies, such as endometrial cancer, endometriosis, and chronic endometritis [53]. Moreover, mounting evidence suggests that epigenetic changes may play a vital role in both placental-induced diseases, such as pre-eclampsia, and intrauterine growth restriction [54,55].

\subsection{Concerns, Limitations and Future Directions}

The results of this systematic review highlight several important avenues for future research. First, no descriptive studies in oocytes were found in the published literature. This is understandable considering the nature of the biologic material (e.g., bioethical impediments, invasive surgical procedures, etc.); however, more efforts are needed to establish the 'normal' miRNA background in this cell type. Second, as we suggested in a previous systematic review of miRNAs on the male reproductive system [47], we emphasize the importance of consistent nomenclature by the use of unequivocal codes such as miRBase Accession Numbers to describe mature miRNAs or the use of the newest codes to distinguish $5 p$ or $3 p$ chains.

Our study has several limitations. First, given that the systematic review only includes descriptive and observational studies, it is not possible to firmly conclude an existing causal relationship between miRNA expression and the risk of infertility or embryo development. Second, the studies identified are highly heterogeneous in terms of the populations analyzed (e.g., healthy women, PCOS, poor ovarian response, etc.), and for the methodologies used to determine the presence and the expression of miRNAs (e.g., qRT-PCR, microarrays, NGS). Third, the normalization methods applied in the different analysis are again highly heterogeneous. This makes impossible to undertake a meta-analysis of the most representative miRNAs in every tissue, weakening the results. However, the results clearly demonstrate that significant efforts are still required to characterize the role of miRNAs in female reproduction and embryogenesis, and it is our hope that this systematic review will be useful in guiding future research in the field.

Taken together, the 27 included studies provide different evidence levels for the role of miRNAs in female infertility and early embryogenesis. However, it is important to note, that the number of high-quality studies has increased significantly in recent years, as 14 of the 27 articles included in this review $(51.8 \%)$ were published since 2015 . Therefore, this article provides a valuable summary of available data for researchers in the field of reproductive medicine with the aim of highlighting the strengths and weakness of existing data and motivating further progress in this complex field of study.

\section{Conclusions}

The present systematic review of descriptive and observational studies demonstrates the general consensus that aberrant miRNA expression in female reproductive tissues/cells and embryos is related with infertility and embryogenesis errors. Moreover, measuring the expression of particular miRNAs, mainly in extracellular vesicles and embryo media, might become useful biomarkers of infertility and may prove to be prognostic of embryo developmental potential. Further studies with uniform methodologies and large samples are needed to clarify the associations described in the present systematic review. 
Supplementary Materials: The following are available online at http://www.mdpi.com/2073-4409/8/12/1564/s1, Table S1: PICOS criteria for inclusion and exclusion of studies. Table S2: Top 10 differentially expressed miRNAs in human reproductive cell/tissues of women and embryos with different conditions related with infertility compared with controls, Appendix S1: Search strategy for the literature published between the earliest available online indexing year and June 2018 in the MEDLINE-Pubmed database and EMBASE, Appendix S2: Quality assessment criteria.

Author Contributions: A.S.-H. and M.Y. initiated the idea of the review, designed the review, collected and selected the data, assessed the articles, wrote the manuscript, and had a primary responsibility for the final content; E.R.J. assessed the articles, created the figures and critically revised the manuscript; K.I.A., T.G.J., and D.T.C. supervised the analysis and critically revised the manuscript. All the authors approved the final manuscript.

Funding: This research was funded by the Ministry of Science, Innovation and Universities, Spain (RYC-2014-15581), and the Regional Government of Catalonia, Spain (2017-SGR-1229).

Acknowledgments: The authors would like to thank Servier Medical Art for their image bank used to assist the creation of figures.

Conflicts of Interest: The authors declare no conflict of interest. The funding agencies had no role in the design, execution, interpretation, or writing of the study.

Prospero Registration Number: PROSPERO 2018: CRD42018099793. Available from http://www.crd.york.ac.uk/ PROSPERO.

\section{References}

1. Ambros, V. microRNAs: Tiny regulators with great potential. Cell 2001, 107, 823-826. [CrossRef]

2. Pasquinelli, A.E. MicroRNAs and their targets: Recognition, regulation and an emerging reciprocal relationship. Nat. Rev. Genet. 2012, 13, 271-282. [CrossRef] [PubMed]

3. Boyd, S.D. Everything you wanted to know about small RNA but were afraid to ask. Lab. Investig. 2008, 88, 569-578. [CrossRef] [PubMed]

4. Inui, M.; Martello, G.; Piccolo, S. MicroRNA control of signal transduction. Nat. Rev. Mol. Cell Biol. 2010, 11, 252-263. [CrossRef] [PubMed]

5. Tétreault, N.; De Guire, V. miRNAs: Their discovery, biogenesis and mechanism of action. Clin. Biochem. 2013, 46, 842-845. [CrossRef] [PubMed]

6. Alles, J.; Fehlmann, T.; Fischer, U.; Backes, C.; Galata, V.; Minet, M.; Hart, M.; Abu-halima, M.; Lenhof, H.; Keller, A.; et al. An estimate of the total number of true human miRNAs. Nucleic Acids Res. 2019, 47, 3353-3364. [CrossRef]

7. Ostermeier, G.C.; Dix, D.J.; Miller, D.; Khatri, P.; Krawetz, S.A. Spermatozoal RNA profiles of normal fertile men. Lancet 2002, 360, 772-777. [CrossRef]

8. Ostermeier, G.C.; Goodrich, R.J.; Moldenhauer, J.S.; Diamond, M.P.; Krawetz, S. A suite of novel human spermatozoal RNAs. J. Androl. 2005, 26, 70-74.

9. Liang, Y.; Ridzon, D.; Wong, L.; Chen, C. Characterization of microRNA expression profiles in normal human tissues. BMC Genom. 2007, 8, 166. [CrossRef]

10. Barad, O.; Meiri, E.; Avniel, A.; Aharonov, R.; Barzilai, A.; Bentwich, I.; Einav, U.; Gilad, S.; Hurban, P.; Karov, Y.; et al. MicroRNA expression detected by oligonucleotide microarrays: System establishment and expression profiling in human tissues. Genome Res. 2004, 14, 2486-2494. [CrossRef]

11. Yadav, R.P.; Kotaja, N. Small RNAs in spermatogenesis. Mol. Cell. Endocrinol. 2013, 382, 498-508. [CrossRef] [PubMed]

12. Toloubeydokhti, T.; Bukulmez, O.; Chegini, N. Potential Regulatory Functions of MicroRNA in the Ovary. Endocrinology 2009, 26, 469-478. [CrossRef] [PubMed]

13. Galliano, D.; Pellicer, A. MicroRNA and implantation. Fertil. Steril. 2014, 101, 1531-1544. [CrossRef] [PubMed]

14. Alvarez-Garcia, I.; Miska, E. MicroRNA functions in animal development and human disease. Development 2005, 132, 4653-4662. [CrossRef] [PubMed]

15. Liberati, A.; Altman, D.G.; Tetzlaff, J.; Mulrow, C.; Goetzsche, P.C.; Ioannidis, J.P.; Clarke, M.; Devereaux, P.; Kleijnen, J.; Moher, D. The PRISMA statement for reporting systematic reviews and meta-analyses of studies that evaluate health care interventions: Explanation and elaboration. J. Clin. Epidemiol. 2009, 62, e1000100. [CrossRef] 
16. Cai, G.; Ma, X.; Chen, B.; Huang, Y.; Liu, S.; Yang, H.; Zou, W. MicroRNA-145 Negatively Regulates Cell Proliferation Through Targeting IRS1 in Isolated Ovarian Granulosa Cells from Patients with Polycystic Ovary Syndrome. Reprod. Sci. 2017, 24, 902-910. [CrossRef]

17. Roth, L.W.; McCallie, B.; Alvero, R.; Schoolcraft, W.B.; Minjarez, D.; Katz-Jaffe, M.G. Altered microRNA and gene expression in the follicular fluid of women with polycystic ovary syndrome. J. Assist. Reprod. Genet. 2014, 31, 355-362. [CrossRef]

18. Scalici, E.; Traver, S.; Mullet, T.; Molinari, N.; Ferrières, A.; Brunet, C.; Belloc, S.; Hamamah, S. Circulating microRNAs in follicular fluid, powerful tools to explore in vitro fertilization process. Sci. Rep. 2016, 6, 24976. [CrossRef]

19. Shi, L.; Liu, S.; Zhao, W.; Shi, J. miR-483-5p and miR-486-5p are down-regulated in cumulus cells of metaphase II oocytes from women with polycystic ovary syndrome. Reprod. Biomed. Online 2015, 31, 565-572. [CrossRef]

20. Wang, M.; Sun, J.; Xu, B.; Chrusciel, M.; Gao, J.; Bazert, M.; Stelmaszewska, J.; Xu, Y.; Zhang, H.; Pawelczyk, L.; et al. Functional characterization of MicroRNA-27a-3p expression in human polycystic ovary syndrome. Endocrinology 2018, 159, 297-309. [CrossRef]

21. Xu, B.; Zhang, Y.W.; Tong, X.H.; Liu, Y.S. Characterization of microRNA profile in human cumulus granulosa cells: Identification of microRNAs that regulate Notch signaling and are associated with PCOS. Mol. Cell. Endocrinol. 2015, 404, 26-36. [CrossRef]

22. Sang, Q.; Yao, Z.; Wang, H.; Feng, R.; Wang, H.; Zhao, X.; Xing, Q.; Jin, L.; He, L.; Wu, L.; et al. Identification of MicroRNAs in Human Follicular Fluid: Characterization of MicroRNAs That Govern Steroidogenesis in Vitro and are Associated with Polycystic Ovary Syndrome in Vivo. J. Clin. Endocrinol. Metab. 2013, 98, 3068-3079. [CrossRef]

23. Santonocito, M.; Vento, M.; Guglielmino, M.R.; Battaglia, R.; Wahlgren, J.; Ragusa, M.; Barbagallo, D.; Borzì, P.; Rizzari, S.; Maugeri, M.; et al. Molecular characterization of exosomes and their microRNA cargo in human follicular fluid: Bioinformatic analysis reveals that exosomal microRNAs control pathways involved in follicular maturation. Fertil. Steril. 2014, 102, 1751-1761. [CrossRef]

24. Tong, X.H.; Xu, B.; Zhang, Y.W.; Liu, Y.S.; Ma, C.H. Research resources: Comparative microRNA profiles in human corona radiata cells and cumulus oophorus cells detected by next-generation small RNA sequencing. PLoS ONE 2014, 9, e106706. [CrossRef]

25. Chen, D.; Zhang, Z.; Chen, B.; Ji, D.; Hao, Y.; Zhou, P.; Wei, Z.; Cao, Y. Altered microRNA and Piwi-interacting RNA profiles in cumulus cells from patients with diminished ovarian reserve. Biol. Reprod. 2017, 97, 91-103. [CrossRef]

26. Diez-Fraile, A.; Lammens, T.; Tilleman, K.; Witkowski, W.; Verhasselt, B.; De Sutter, P.; Benoit, Y.; Espeel, M.; D'Herde, K. Age-associated differential microRNA levels in human follicular fluid reveal pathways potentially determining fertility and success of in vitro fertilization. Hum. Fertil. 2014, 17, 90-98. [CrossRef]

27. Eisenberg, I.; Nahmias, N.; Novoselsky Persky, M.; Greenfield, C.; Goldman-Wohl, D.; Hurwitz, A.; Haimov-Kochman, R.; Yagel, S.; Imbar, T. Elevated circulating micro-ribonucleic acid (miRNA)-200b and miRNA-429 levels in anovulatory women. Fertil. Steril. 2017, 107, 269-275. [CrossRef]

28. Fu, J.; Qu, R.; Zhang, Y.; Gu, R.; Li, X.; Sun, Y.; Wang, L.; Sang, Q.; Sun, X. Screening of miRNAs in human follicular fluid reveals an inverse relationship between microRNA-663b expression and blastocyst formation. Reprod. Biomed. Online 2018, 37, 25-32. [CrossRef]

29. Karakaya, C.; Guzeloglu-Kayisli, O.; Uyar, A.; Kallen, A.N.; Babayev, E.; Bozkurt, N.; Unsal, E.; Karabacak, O.; Seli, E. Poor ovarian response in women undergoing in vitro fertilization is associated with altered microRNA expression in cumulus cells. Fertil. Steril. 2015, 103, 1469-1476. [CrossRef]

30. Luo, H.; Han, Y.; Liu, J.; Zhang, Y. Identification of microRNAs in granulosa cells from patients with different levels of ovarian reserve function and the potential regulatory function of miR-23a in granulosa cell apoptosis. Gene 2019, 686, 250-260. [CrossRef]

31. Martinez, R.M.; Liang, L.; Racowsky, C.; Dioni, L.; Mansur, A.; Adir, M.; Bollati, V.; Baccarelli, A.A.; Hauser, R.; Machtinger, R. Extracellular microRNAs profile in human follicular fluid and IVF outcomes. Sci. Rep. 2018, 8, 17036. [CrossRef]

32. Moreno, J.M.; Núñez, M.J.; Quiñonero, A.; Martínez, S.; De La Orden, M.; Simón, C.; Pellicer, A.; Díaz-García, C.; Domínguez, F. Follicular fluid and mural granulosa cells microRNA profiles vary in in vitro fertilization patients depending on their age and oocyte maturation stage. Fertil. Steril. 2015, 104, 1037-1046. [CrossRef] 
33. Barragán, M.; Pons, J.; Ferrer-Vaquer, A.; Cornet-Bartolomé, D.; Schweitzer, A.; Hubbard, J.; Auer, H.; Rodolosse, A.; Vassena, R. The transcriptome of human oocytes is related to age and ovarian reserve. Mol. Hum. Reprod. 2017, 23, 535-548. [CrossRef]

34. Xu, Y.W.; Wang, B.; Ding, C.H.; Li, T.; Gu, F.; Zhou, C. Differentially expressed micoRNAs in human oocytes. J. Assist. Reprod. Genet. 2011, 28, 559-566. [CrossRef]

35. Battaglia, R.; Vento, M.E.; Ragusa, M.; Barbagallo, D.; La Ferlita, A.; Di Emidio, G.; Borzi, P.; Artini, P.G.; Scollo, P.; Tatone, C.; et al. MicroRNAs Are Stored in Human MII Oocyte and Their Expression Profile Changes in Reproductive Aging. Biol. Reprod. 2016, 95, 131. [CrossRef]

36. Dominguez, F.; Moreno-Moya, J.M.; Lozoya, T.; Romero, A.; Martínez, S.; Monterde, M.; Gurrea, M.; Ferri, B.; Núñez, M.J.; Simón, C.; et al. Embryonic miRNA profiles of normal and ectopic pregnancies. PLoS ONE 2014, 9, e102185. [CrossRef]

37. McCallie, B.; Schoolcraft, W.B.; Katz-Jaffe, M.G. Aberration of blastocyst microRNA expression is associated with human infertility. Fertil. Steril. 2010, 93, 2374-2382. [CrossRef]

38. Rosenbluth, E.M.; Shelton, D.N.; Sparks, A.E.T.; Devor, E.; Christenson, L.; Van Voorhis, B.J. MicroRNA expression in the human blastocyst. Fertil. Steril. 2013, 99, 855-861. [CrossRef]

39. McCallie, B.R.; Parks, J.C.; Strieby, A.L.; Schoolcraft, W.B.; Katz-Jaffe, M.G. Human blastocysts exhibit unique microrna profiles in relation to maternal age and chromosome constitution. J. Assist. Reprod. Genet. 2014, 31, 913-919. [CrossRef]

40. Lozoya, T.; Domínguez, F.; Romero-Ruiz, A.; Steffani, L.; Martínez, S.; Monterde, M.; Ferri, B.; Núñez, M.J.; Romero-Espinós, A.; Zamora, O.; et al. The Lin28/Let-7 system in early human embryonic tissue and ectopic pregnancy. PLoS ONE 2014, 9, e87698. [CrossRef]

41. Capalbo, A.; Ubaldi, F.M.; Cimadomo, D.; Noli, L.; Khalaf, Y.; Farcomeni, A.; Ilic, D.; Rienzi, L. MicroRNAs in spent blastocyst culture medium are derived from trophectoderm cells and can be explored for human embryo reproductive competence assessment. Fertil. Steril. 2016, 105, 225-235. [CrossRef]

42. Rosenbluth, E.M.; Shelton, D.N.; Wells, L.M.; Sparks, A.E.T.; Van Voorhis, B.J. Human embryos secrete microRNAs into culture media-A potential biomarker for implantation. Fertil. Steril. 2014, 101, 1493-1500. [CrossRef]

43. Lena, A.M.; Mancini, M.; Rivetti di Val Cervo, P.; Saintigny, G.; Mahé, C.; Melino, G.; Candi, E. MicroRNA-191 triggers keratinocytes senescence by SATB1 and CDK6 downregulation. Biochem. Biophys. Res. Commun. 2012, 423, 509-514. [CrossRef]

44. Cook, J.; Bennett, P.R.; Kim, S.H.; Teoh, T.G.; Sykes, L.; Kindinger, L.M.; Garrett, A.; Binkhamis, R.; MacIntyre, D.A.; Terzidou, V. First Trimester Circulating MicroRNA Biomarkers Predictive of Subsequent Preterm Delivery and Cervical Shortening. Sci. Rep. 2019, 9, 1-9. [CrossRef]

45. Rodosthenous, R.S.; Burris, H.H.; Sanders, A.P.; Just, A.C.; Dereix, A.E.; Svensson, K.; Solano, M.; Téllez-Rojo, M.M.; Wright, R.O.; Baccarelli, A.A. Second trimester extracellular microRNAs in maternal blood and fetal growth: An exploratory study. Epigenetics 2017, 12, 804-810. [CrossRef]

46. Singh, K.; Williams, J.; Brown, J.; Wang, E.T.; Lee, B.; Gonzalez, T.L.; Cui, J.; Goodarzi, M.O.; Pisarska, M.D. Up-regulation of microRNA-202-3p in first trimester placenta of pregnancies destined to develop severe preeclampsia, a pilot study. Pregnancy Hypertens. 2017, 10, 7-9. [CrossRef]

47. Salas-Huetos, A.; James, E.R.; Aston, K.I.; Carrell, D.T.; Jenkins, T.G.; Yeste, M. The role of miRNAs in male human reproduction: A systematic review. Andrology 2019, in press. [CrossRef]

48. Feng, R.; Sang, Q.; Zhu, Y.; Fu, W.; Liu, M.; Xu, Y.; Shi, H.; Xu, Y.; Qu, R.; Chai, R.; et al. MiRNA-320 in the human follicular fluid is associated with embryo quality in vivo and affects mouse embryonic development in vitro. Sci. Rep. 2015, 5, 8689. [CrossRef]

49. Sun, Y.X.; Zhang, Y.X.; Zhang, D.; Xu, C.M.; Chen, S.C.; Zhang, J.Y.; Ruan, Y.C.; Chen, F.; Zhang, R.J.; Qian, Y.Q.; et al. XCI-escaping gene KDM5C contributes to ovarian development via downregulating miR-320a. Hum. Genet. 2017, 136, 227-239. [CrossRef]

50. Zeng, Y.; Rosborough, R.C.; Li, Y.; Gupta, A.R.; Bennett, J. Temporal and spatial regulation of gene expression mediated by the promoter for the human tissue inhibitor of metalloproteinases-3 (TIMP-3)- encoding gene. Dev. Dyn. 1998, 211, 228-237. [CrossRef]

51. Ketley, A.; Warren, A.; Holmes, E.; Gering, M.; Aboobaker, A.A.; Brook, J.D. The miR-30 MicroRNA Family Targets smoothened to Regulate Hedgehog Signalling in Zebrafish Early Muscle Development. PLoS ONE 2013, 8, e65170. [CrossRef] 
52. Zhao, K.; Chen, Y.; Yang, R.; Bai, Y.; Li, C.; Li, H.; Xiong, C. miR-424/322 is downregulated in the semen of patients with severe DNA damage and may regulate sperm DNA damage. Reprod. Fertil. Dev. 2015, 28, 1598-1607. [CrossRef] [PubMed]

53. La Ferlita, A.; Battaglia, R.; Andronico, F.; Caruso, S.; Cianci, A.; Purrello, M.; Di Pietro, C. Non-coding RNAs in endometrial physiopathology. Int. J. Mol. Sci. 2018, 19, 2120. [CrossRef] [PubMed]

54. Chiofalo, B.; Laganà, A.S.; Vaiarelli, A.; La Rosa, V.L.; Rossetti, D.; Palmara, V.; Valenti, G.; Rapisarda, A.M.C.; Granese, R.; Sapia, F.; et al. Do miRNAs play a role in fetal growth restriction? A fresh look to a busy corner. Biomed Res. Int. 2017, 2017, 6073167. [CrossRef] [PubMed]

55. Lycoudi, A.; Mavreli, D.; Mavrou, A.; Papantoniou, N.; Kolialexi, A. MIRNAs in pregnancy-related complications. Expert Rev. Mol. Diagn. 2015, 15, 999-1010. [CrossRef] [PubMed]

(C) 2019 by the authors. Licensee MDPI, Basel, Switzerland. This article is an open access article distributed under the terms and conditions of the Creative Commons Attribution (CC BY) license (http://creativecommons.org/licenses/by/4.0/). 